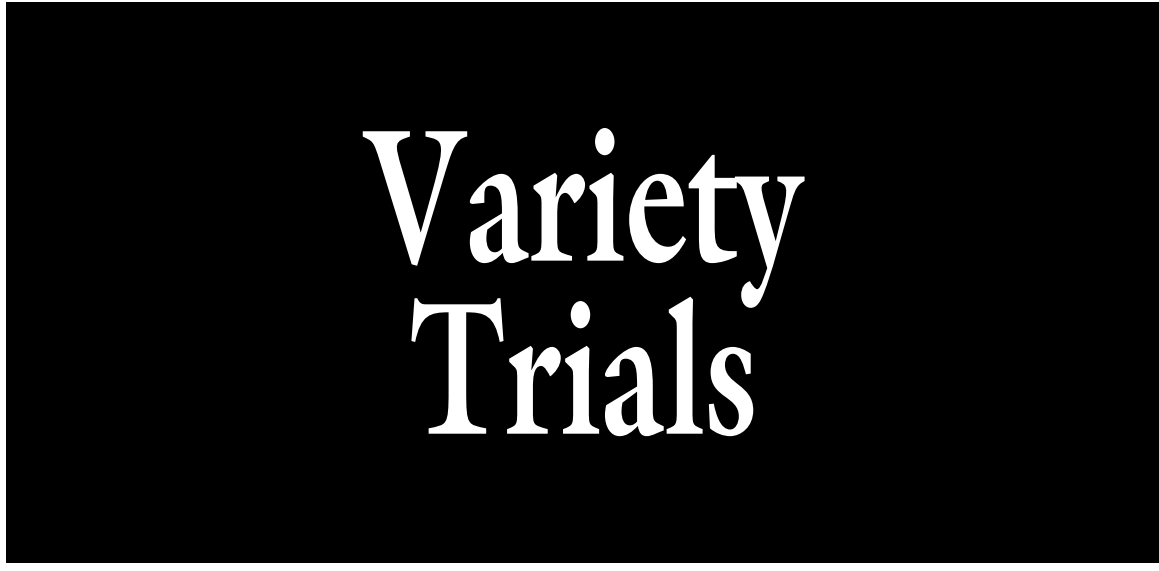

\title{
Performance of Landscape Roses Grown with Minimal Input in the North-central, Central, and South-central United States
}

\author{
David C. Zlesak ${ }^{1,8}$, Randy Nelson ${ }^{2}$, Derald Harp ${ }^{3}$, \\ Barbara Villarreal ${ }^{3}$, Nick Howell ${ }^{4}$, Jason Griffin ${ }^{5}$, \\ Gaye Hammond ${ }^{6}$, and Steve George ${ }^{7}$
}

AdDitional InDEX wORDs. black spot, cane survival, Earth-Kind ${ }^{\circledR}$, Rosa bybrida, shrub roses, winterhardiness

SUMMARY. Landscape roses (Rosa sp.) are popular flowering shrubs. Consumers are less willing or able to maintain landscape beds than in years past and require plants that are not only attractive, but well-adapted to regional climatic conditions, soil types, and disease and pest pressures. Marketing and distribution of rose cultivars occurs on a national level; therefore, it is difficult for U.S. consumers in the U.S. Department of Agriculture (USDA) Plant Hardiness Zones 3 to 5 to identify welladapted, cold-hardy cultivars. Identifying suitable cultivars that have strong genetic resistance to pests and disease and that will tolerate temperature extremes without winter protection in the USDA Plant Hardiness Zones 3 to 5 is of tremendous value to consumers and retailers in northern states. Twenty landscape rose cultivars, primarily developed in north-central North America, were evaluated at five locations in the United States (three in the north-central United States, one in the central United States, and one in the south-central United States) using the lowinput, multiyear Earth-Kind ${ }^{\circledR}$ methodology. Six roses had $\geq 75 \%$ plant survival at the end of the study and were in the top $50 \%$ of performers for overall mean horticultural rating at each of the three north-central U.S. sites: 'Lena', 'Frontenac', 'Ole', 'Polar Joy', 'Sunrise Sunset', and 'Sven'. Five of these six roses met the same criteria at the central United States (exception 'Lena') and the south-central United States (exception 'Polar Joy') sites. Cultivar, rating time, and their interaction were highly significant, and block effects were not significant for horticultural rating for all single-site analyses of variance. Significant positive correlations were found between sites for flower number, flower diameter, and overall horticultural rating. Significant negative correlations were found between flower number and diameter within each site and also between black spot (Diplocarpon rosae) lesion size from a previous study and overall horticultural rating for three of the five sites. Cane survival ratings were not significantly correlated with overall horticultural rating, suggesting some cultivars can experience severe winter cane dieback, yet recover and perform well. Data from this study benefit multiple stakeholders, including nurseries, landscapers, and consumers, with evidence-based regional cultivar recommendations and breeders desiring to identify regionally adapted parents.

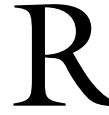

oses are the world's most popular garden and cut-flower plant (Waliczek et al., 2015).
Researchers in the United States and Canada have undertaken comprehensive consumer preference studies that benefit rose hybridizers as they develop cultivars to meet the needs of consumers and growers (Grygorczyk et al., 2013). Today's consumers are less willing or able to spend time maintaining landscape beds than in years past and are also increasingly hesitant to grow pesticide-dependent landscape plants (Harp et al., 2009; Waliczek et al., 2015). They require plants that are not only attractive, but well-adapted to regional climatic conditions, soil types, and disease and pest pressures. In addition, consumers residing in colder northern climates have expectations that roses marketed as "cold hardy" should withstand temperatures at least slightly colder than their plant hardiness zone to help ensure survival (Grygorczyk et al., 2013). Cultivars developed to combine improved disease resistance, greater climatic adaptability (heat, cold, drought, etc.), increased tolerance to different soil types, and a wider range of ornamental characteristics have helped make the transition to lower maintenance roses possible.

Shrub roses (term for a specific horticultural class of roses and also commonly used interchangeably in the marketplace as landscape roses) have the connotation of being lower maintenance plants than other horticultural classifications of roses (e.g., hybrid tea and miniature roses) and are meant for outdoor planting. Lower maintenance landscape or shrub roses have steadily increased in popularity in recent decades. Their sales in the United States represented about $20 \%$ of rose plants sold in the 1980s, about $50 \%$ in 2013, and is projected to be $60 \%$ of total U.S. rose sales meant for outdoor planting by 2018 (Pemberton and Karlik, 2015).

Advertisers routinely use the terms "disease resistant" and "hardy" when marketing roses to consumers and commonly distribute the same landscape rose cultivars nationally across diverse geographic regions, soil types, and climates. Advertising claims are sometimes unclear as to which diseases a cultivar is resistant, the relative degree of resistance, or exactly what is meant by the term "hardy" (e.g., cold hardy, heat tolerant, or drought tolerant).

Most of the landscape rose cultivars available today are not reliably winter hardy in the USDA Plant Hardiness Zones 3 and 4 (U.S. Department of Agriculture, 2012; 
Zuzek et al., 2016). In regions with cold winter temperatures, the coldest USDA plant hardiness zone for a cultivar is an important factor guiding purchasing decisions of astute customers (Grygorczyk et al., 2013). Typically, the coldest recommended rating means the rose is likely to survive in that designated zone, but may require additional insulation (winter protection) to prevent extensive cane dieback or death.

The necessity to provide winter protection conflicts with consumer demands for low maintenance landscapes. With most nationally marketed shrub roses designated in catalogs and plant tags as hardy to USDA Plant Hardiness Zone 5, identifying suitable cultivars that have strong genetic resistance to pests and disease and that will tolerate

We thank the many generous volunteers (e.g., Master Gardeners and rose society members) that helped make this research possible. There were three additional trial sites in Bellevue, NE (led by Kathleen Cue, Anita Eckley, and Joanne Langabee), Fort Collins, $\mathrm{CO}$ (led by Tamla Blunt), and Crookston, $\mathrm{MN}$ (led by Eric Castle) that were planted and established, but unfortunately lost due to flooding or wildlife before complete sets of data were collected. We wish to acknowledge Linda Farris for plot maintenance and all data collection at the Haysville, KS location. In addition, we acknowledge and thank: Bailey Nurseries Inc., Bergeson Nursery, Star ${ }^{\circledR}$ Roses and Plants, Greenheart Farms, Inc., Holland's Landscaping and Garden Center, and Sam Kedem Nursery \& Garden for their generous donations of roses for this trial; Christian A. Thill and Jeffrey Gillman at the University of Minnesota for use of facilities to hold plant material until distribution; and Arunendu Chatterjee for his assistance with statistical analyses. We also thank: the city of Moorhead, MN, for supplying land, compost, and mulch for the trials and preparing the land for planting, the Northwest Regional Sustainable Development Partnership for a grant to support the Moorhead, MN site, the University of Minnesota Outreach, Research, and Education Park for land for the trial and site preparation, The Mulch Store for their donation of compost at the Rosemount, MN site, and the Greater Milwaukee Rose Society for the financial support that covered the publication costs of this research.

${ }^{1}$ University of Wisconsin-River Falls, 410 South 3rd Street, River Falls, WI 54022

${ }^{2}$ University of Minnesota Extension-Clay County, 715 11th Street North, Suite 107B, Moorhead, MN 56560

${ }^{3}$ School of Agriculture, Texas A\&M University Commerce, P.O. Box 3011, Commerce, TX 75429

${ }^{4}$ Horticulture Research Station, Iowa State University, 55519 170th Street, Ames, IA 50010

${ }^{5}$ Kansas State University, John C. Pair Horticulture Center, 1901 East 95th Street South, Haysville, KS 67060

${ }^{6}$ Houston Rose Society, 5020 Montrose Boulevard, 9th Floor, Houston, TX 77006

${ }^{7}$ Texas A\&M AgriLife Research and Extension Service, 17360 Coit Road, Dallas, TX 75252

${ }^{8}$ Corresponding author. E-mail: david.zlesak@uwrf. edu.

doi: 10.21273/HORTTECH03681-17 temperature extremes without winter protection in USDA Plant Hardiness Zones 3 to 5 is of tremendous value to consumers and retailers in northern states.

The Texas A\&M Earth-Kind ${ }^{\circledR}$ Environmental Landscape Management Program has been conducting rose trials under low-input conditions since the 1990s. Trials are conducted over multiple years and locations and use well-defined, low-input protocols (Harp et al., 2009; Mackay et al., 2008; Zlesak et al., 2015). Cultivars with consistently high performance across regional sites earn the designation of being an Earth-Kind ${ }^{\circledR}$ rose for the particular region.

With basic plant care, consumers are very likely to be successful with Earth-Kind ${ }^{\circledR}$ cultivars because they have been selected based on years of data supporting their regional adaptation. Earth-Kind ${ }^{\circledR}$ rose trialing efforts are ongoing with new trials being initiated as promising cultivars enter the marketplace. Earth-Kind ${ }^{\circledR}$ rose trials have expanded outside of Texas and the greater south-central region of the United States. Horticulturists in other regions have been encouraged to partner with the EarthKind $^{\circledR}$ program using the wellestablished Earth-Kind ${ }^{\circledR}$ trialing protocols developed in Texas and modify them, as necessary, based on unique regional conditions (Harp et al., 2009; Zlesak et al., 2015).

The objective of this study was to evaluate a collection of landscape rose cultivars with preliminary or anecdotal evidence for having desirable ornamental characteristics under minimal input conditions in the north-central United States (USDA Plant Hardiness Zones 3 to 5), central United States, and south-central United States using low-input EarthKind ${ }^{\circledR}$ rose trialing methodology.

\section{Materials and methods Plant materials}

Twenty rose cultivars were selected for field evaluation based on recommendations by landscapers, nursery and public garden professionals, and American Rose Society members in the north-central United States (Table 1). Roses included cultivars from the rose breeding programs at Iowa State University (led by Griffith J. Buck) and two Agriculture Canada sponsored rose breeding programs: the Explorer series (led by Felicitas Svejda, Central Experimental Farm, Ottawa, ON, Canada, and then later by Ian Ogilvie, L'Assomption, QC, Canada) and the Parkland or Morden series (led by Lynn Collicutt and Henry Marshall, Morden Research Station, Morden, MB, Canada) (American Rose Society, 2007; Svejda, 2008, 2014).

Newer rose cultivars showing promise in regional landscapes were also included from three midwest U.S-based rose breeding programs: Ping Lim's program at Bailey Nurseries, Inc. (Newport, MN); Kathy Zuzek and Stan Hokanson's program at the University of Minnesota Horticultural Research Center, Chaska, $\mathrm{MN}$; and William Radler's program at Rose Innovations, Inc., Greenfield, WI. Two of the 20 roses ('Carefree Beauty' and 'Sea Foam') have previously received the Earth-Kind ${ }^{\circledR}$ designation for the south-central United States, and 'Carefree Beauty' is routinely used as the control or reference cultivar in ongoing Earth-Kind ${ }^{\circledR}$ rose trials.

All roses were propagated from stem cuttings and not grafted ("own root") to avoid graft incompatibilities and unpredictable rootstock and scion interactions (Richer et al., 2005). The roses were obtained as 2-year-old dormant plants and came from multiple nurseries.

\section{Trial sites}

Cultivars were evaluated at five sites in the United States representing USDA Plant Hardiness Zones $4 \mathrm{a}$ in the extreme north to Zone 8a at the southernmost location. The three north-central U.S. trial sites and

\begin{tabular}{llll}
\hline $\begin{array}{l}\text { Units } \\
\begin{array}{l}\text { To convert U.S. to SI, } \\
\text { multiply by }\end{array}\end{array}$ & U.S. unit & SI unit & $\begin{array}{l}\text { To convert SI to U.S., } \\
\text { multiply by }\end{array}$ \\
\hline 0.3048 & $\mathrm{ft}$ & $\mathrm{m}$ & 3.2808 \\
2.54 & inch(es) & $\mathrm{cm}$ & 0.3937 \\
25.4 & inch $(\mathrm{es})$ & $\mathrm{mm}$ & 0.0394 \\
$\left({ }^{\circ} \mathrm{F}-32\right) \div 1.8$ & ${ }^{\circ} \mathrm{F}$ & ${ }^{\circ} \mathrm{C}$ & $\left({ }^{\circ} \mathrm{C} \times 1.8\right)+32$
\end{tabular}


Table 1. The commercial class, flower color, year of introduction, origin, ploidy, and black spot lesion length of 20 landscape roses.

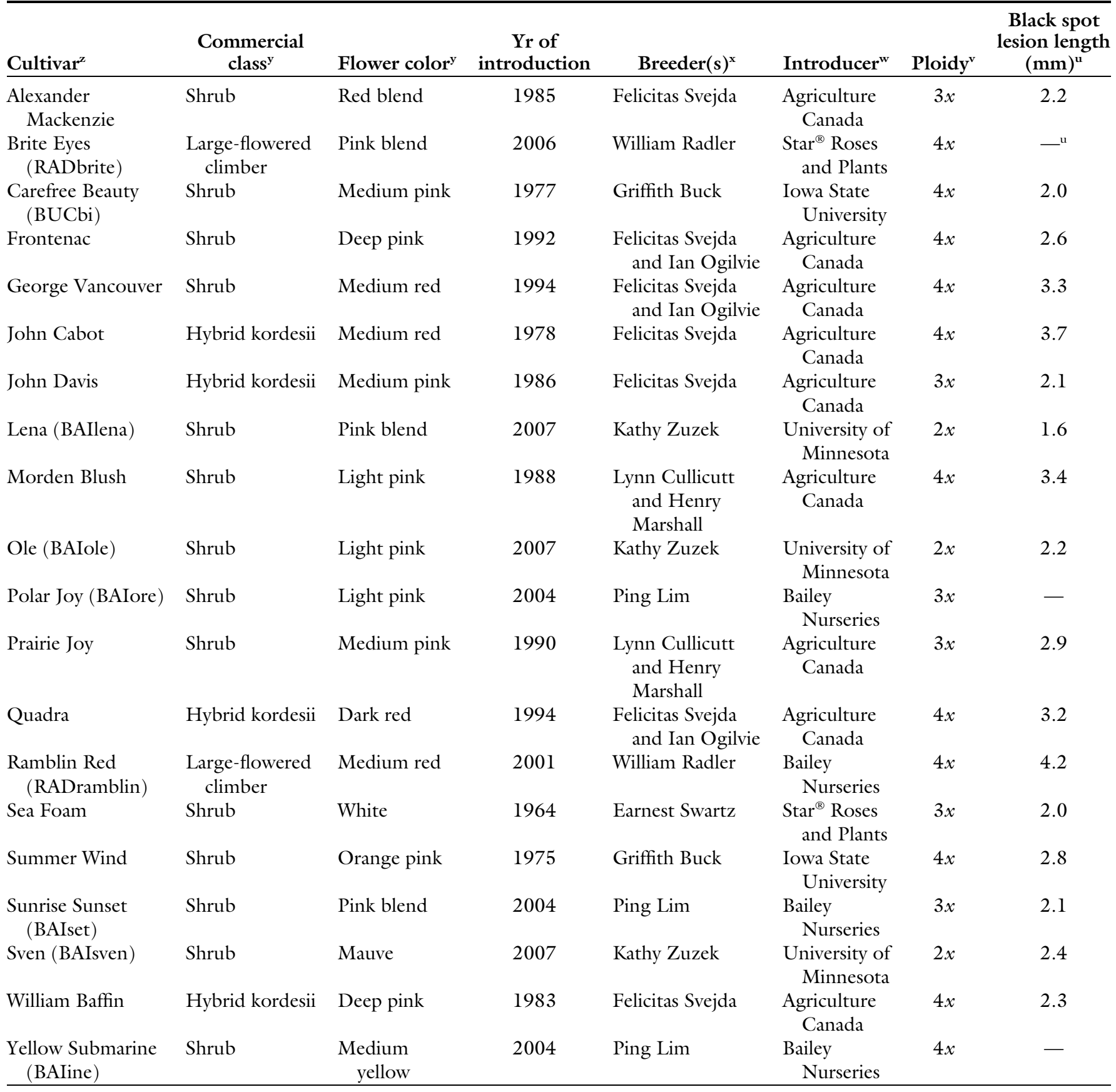

${ }^{\mathrm{z}}$ Cultivar name or trademark followed by cultivar name in parentheses.

${ }^{y}$ Reported by the American Rose Society (2007).

${ }^{x}$ Reported by the American Rose Society (2007) and Svejda $(2008,2014)$.

${ }^{\text {w} A g r i c u l t u r e ~ C a n a d a ~(O t t a w a, ~ O N, ~ C a n a d a), ~ B a i l e y ~ N u r s e r i e s ~(N e w p o r t, ~ M N), ~ I o w a ~ S t a t e ~ U n i v e r s i t y ~(A m e s, ~ I A), ~ S t a r ~}{ }^{\circledR}$ Roses and Plants (West Grove, PA), University of Minnesota (Minneapolis, $\mathrm{MN}$ )

${ }^{\mathrm{v}}$ Reported in Zlesak et al. (2010).

"Mean black spot lesion length in controlled innoculations with race three of Diplocarpon rosae (Zlesak et al., 2010). Brite Eyes and Yellow Submarine were not susceptible to this race and Polar Joy, although susceptible, could not be measured because of accelerated leaf deterioration; $1 \mathrm{~mm}=0.0394$ inch.

USDA Plant Hardiness Zones were Centennial Park, Moorhead, $\mathrm{MN}$ (Zone 4a); University of Minnesota Outreach, Research, and Education Park, Rosemount, MN (Zone 4b); and Iowa State University Horticulture Research Station, Ames, IA (Zone 5a).
Two additional sites in the central United States and south-central United States (Zones 6b and 8a) were included to learn how these northern-bred roses performed in warmer climates and which cultivars demonstrated promise for widespread trialing in those regions. The central United States research site was located at the Kansas State University, John C. Pair Horticultural Center [Haysville, KS (Zone $6 \mathrm{~b})$ ], and the south-central United States research site was located at Texas A\&M University-Commerce 
[Commerce, TX (Zone 8a)]. By trialing in north-central United States, central United States, and southcentral United States climates, it is possible to expand our understanding of the potential range of cultivar adaptation.

\section{Bed preparation and care}

Roses were planted and cared for using Earth-Kind ${ }^{\circledR}$ trialing protocols (Harp et al., 2009; Zlesak et al., 2015). Glyphosate was sprayed at recommended rates to clear beds of perennial weeds before planting. Soil tests were taken to document soil conditions at the time of planting. A 3 to 4 -inch layer of finished local compost was incorporated into beds 8-10 inches deep preplant, and a 2.5 to 4.0 -inch layer of organic mulch (typically donated wood chips from local arborists) was maintained on the beds throughout the study. Initial compost and the decomposition of organic mulch provided ongoing nutrition throughout the study, and no supplemental fertilizer was used. No fungicides, insecticides, or other pesticides were sprayed on the plants to document and compare cultivars for tolerance to regional pests and diseases. All planting beds received at least $8 \mathrm{~h}$ of full sun per day during the growing season. No supplemental winter protection or insulation, other than the already existing mulch and natural snow, was provided to the plants throughout the study.

The experimental design was a randomized complete block design with four blocks and one plant per cultivar per block. Spacing between plants was 6 $\mathrm{ft}$ at all sites except $8 \mathrm{ft}$ at the Commerce, TX site because of the longer growing season and larger anticipated plant size. Plants were irrigated as needed during the first growing season to ensure $\approx \mathrm{l}$ inch of total precipitation per week from both natural rainfall and irrigation. Plants were not given supplemental irrigation in the second year through the end of the study.

\section{Data collection}

Data collection began during the second growing season at four of the trial sites and during the third growing season at the Moorhead, MN site. Delaying data collection until the second (or third) growing season allowed for plants to become established and for dissipation of residual pesticides and fertilizers that may have been applied at nurseries before plants were received at the research sites.

Data were collected monthly on a per-plant basis during the growing season while plants were blooming. A horticultural rating was determined using a criterion-referenced scale from 1 (weak performance) to 10 (strong performance) with three indices (flower quantity and quality, foliage quantity and quality, and plant habit and vigor) as described by Mackay et al. (2008). Monthly flower number and average flower diameter (mean of up to three typical flowers) were also recorded. Plant height (height of tallest cane) and width (average of two perpendicular measurements) were recorded at the end of the study in the northcentral U.S. locations. Winterhardiness of the cultivars was evaluated each spring at the north-central U.S. and central U.S. trial sites by using a 1 to 10 scale for cane survival (e.g., $1=$ plant is alive with up to $10 \%$ cane survival above the soil, $5=41 \%$ to $50 \%$ cane survival, and $10=91 \%$ to $100 \%$ cane survival).

\section{North-central U.S. trial sites}

AMES, IA (USDA Plant Hardiness Zone 5A). Roses were field planted as dormant plants in midSpring 2008. The soil was a Clarion loam (fine-loamy, mixed, superactive, mesic, Typic Hapludolls; $\mathrm{pH}=6.8$ ). Monthly data collection occurred from June to Sept. 2009 to 2011.

MOORHEAD, MN (USDA PLANT Hardiness Zone 4A). Dormant roses were directly planted during mid-Spring 2008. The soil was a Bearden silty clay loam (fine-silty, mixed, superactive, frigid, and Aeric Calciaquolls; $\mathrm{pH}=7.9$ ). Because of being directly planted as dormant plants, slower plant establishment from the shorter growing season, and a loss of plants $(<10 \%)$ and subsequent replacement, roses were allowed to grow 2 years before data collection began. At the end of 2 years, plants were comparably established to plants growing at the warmer sites. Monthly data collection occurred from June to Sept. 2010 to 2012.

Rosemount, MN (USDA PLANT Hardiness Zone 4B). Roses were potted in standard No. 2 nursery containers and were initially grown outdoors on a gravel bed beginning in mid-Mar. 2007 because of planting beds not being ready at that time. In
June 2007 (about 10 weeks later), the roses were well rooted in the containers and transplanted to the field site. The soil was a Waukegan silt loam (fine-silty over sandy or sandyskeletal, mixed, superactive, mesic, and Typic Hapludolls; $\mathrm{pH}=6.3$ ). Monthly data collection occurred from June to Sept. 2008 to 2011. Plants were maintained for five growing seasons at this site, and data were recorded over four growing seasons, 1 year more than was possible at the other north-central U.S. sites.

\section{Central U.S. and south-central U.S. trial sites}

Harsville, KS (USDA Plant Hardiness Zone 6B). Bare-root roses were received in Spring 2007 and immediately potted into standard No. 2 nursery containers and maintained on a gravel pad with overhead irrigation throughout the growing season. Plants were overwintered in an unheated white polyethylene covered hoop house and field planted in Spring 2008. The soil was a Canadian-Waldeck fine sandy loam (coarse-loamy, mixed, superactive, thermic, and Fluvaquentic Haplustolls; $\mathrm{pH}=6.7$ ). Collection of monthly horticultural rating data occurred from May to Oct. 2009 and 2010, with flower number and diameter data collected monthly from May through Oct. 2010. Plant height and width data were not recorded.

Commerce, TX (USDA Plant Hardiness Zone 8A). Bare-root roses were received in Mar. 2008, which is beyond the recommended planting date for bare-root roses in TX. Therefore, plants were potted into standard No. 2 nursery containers and maintained in a shaded greenhouse in Commerce, TX, until Fall 2008 when they were planted in the field. Soil at the site was a Crockett silt loam (fine, smectitic, thermic, and Udertic Paleustalf; $\mathrm{pH}=7.0$ ). Monthly data collection occurred from July to Nov. 2009, from Apr. to Nov. 2010, and from Apr. to Aug. 2011. Data collection ended in Aug. 2011 due to extreme heat (temperatures consistently above $100^{\circ} \mathrm{F}$ on a daily basis) and exceptional drought (pan evaporation $>70 \mathrm{~mm} /$ week) forcing plants to go into premature dormancy. To report yearly means that are complete for this site and to take into account the challenges 
imposed by the extreme drought, data from July 2009 to June 2010 and from July 2010 to June 2011 was used for reporting and analyses and comprised two official calendar years' worth of data.

\section{Statistical analysis}

Means and standard errors were calculated for the data. A univariate analysis of variance (ANOVA) was performed for each site as well as the northcentral U.S. trial sites, collectively, for horticultural rating. Tukey's honest significant difference test [HSD $(P \leq 0.05)]$ was used for mean separations. Independent variables in the model were cultivar and rating time (each sequential monthly rating), and the block was a random variable. For the combined north-central U.S. trial analysis, the fourth year of field data from Rosemount, $\mathrm{MN}$, was excluded so that all sites had 3 years of field data analyzed, and trial site was an independent variable. Pearson's correlation was used to explore associations between data collected for traits within and across sites. Statistical analyses were performed using IBM SPSS Statistics for Windows (version 23.0; IBM, Armonk, NY).

\section{Results}

The minimum winter temperature varied from year to year at each site and typically occurred during the month of January (Table 2). Moorhead, $\mathrm{MN}$, had the greatest range in minimum winter temperatures between trial years (16.0 ${ }^{\circ} \mathrm{F}$ ) and Haysville, KS, the least $\left(6.1^{\circ} \mathrm{F}\right)$. Corresponding USDA Plant Hardiness Zone based on actual yearly minimum temperatures experienced at each location are also presented by year.

The Ames, IA site had winters with actual temperatures a half zone and one full zone colder and one winter a half zone warmer than the site's official zone designation (Table 2 ). The Moorhead, MN site had actual winter temperatures 1 year within the site's official zone designation, one a half zone colder and one a full zone warmer. The Rosemount, MN site had actual winter temperatures within the site's official zone designation, two winters and one winter a half zone warmer and another winter a half zone colder. The Haysville, KS, and Commerce, TX sites had actual winter temperatures within the site's official zone designation one winter and warmer the remaining winters.

Plant survival, monthly horticultural rating, monthly flower number, flower diameter, spring cane survival, and mature plant size are reported by cultivar by site (Tables 3-7). Spring cane survival ratings were not made at the south-central research site (Commerce, TX) as minimum winter

Table 2. Yearly minimum temperature with date experienced for landscape rose trial sites the winter before spring cane survival measurements were taken.

\begin{tabular}{|c|c|c|c|}
\hline Location & $\begin{array}{l}\text { Date of yearly } \\
\text { minimum temp }\end{array}$ & $\begin{array}{l}\text { Minimum } \\
\text { temp }\left({ }^{\circ} \mathbf{F}\right)^{z}\end{array}$ & Zone $^{\mathrm{y}}$ \\
\hline \multicolumn{4}{|c|}{ North-central U.S. locations } \\
\hline \multirow[t]{3}{*}{ Ames, IA } & 15 Jan. 2009 & -25.1 & $4 \mathrm{a}$ \\
\hline & 2 Jan. 2010 & -20.9 & $4 b$ \\
\hline & 8 Feb. 2011 & -11.9 & $5 b$ \\
\hline \multirow[t]{3}{*}{ Moorhead, MN } & 2 Jan. 2010 & -33.0 & $3 b$ \\
\hline & 21 Jan. 2011 & -27.0 & $4 \mathrm{a}$ \\
\hline & 19 Jan. 2012 & -17.0 & $5 a$ \\
\hline \multirow[t]{4}{*}{ Rosemount, $\mathrm{MN}$} & 20 Jan. 2008 & -18.0 & $5 a$ \\
\hline & 16 Jan. 2009 & -27.9 & $4 \mathrm{a}$ \\
\hline & 3 Jan. 2010 & -22.0 & $4 b$ \\
\hline & 21 Jan. 2011 & -24.0 & $4 b$ \\
\hline \multicolumn{4}{|l|}{ Central U.S. location } \\
\hline \multirow[t]{2}{*}{ Haysville, KS } & 28 Jan. 2009 & 3.2 & $7 \mathrm{a}$ \\
\hline & 9 Jan. 2010 & -2.9 & $6 b$ \\
\hline \multicolumn{4}{|c|}{ South-central U.S. location } \\
\hline \multirow[t]{3}{*}{ Commerce, TX } & 17 Jan. 2009 & 19.0 & $8 b$ \\
\hline & 9 Jan. 2010 & 10.9 & $8 a$ \\
\hline & 12 Jan. 2011 & 16.0 & $8 \mathrm{~b}$ \\
\hline
\end{tabular}

${ }^{\mathrm{z}}$ Temperature and date data were obtained from Your Weather Service $(2017) ;\left({ }^{\circ} \mathrm{F}-32\right) \div 1.8={ }^{\circ} \mathrm{C}$.

${ }^{y}$ Corresponding USDA Plant Hardiness Zone experienced each winter at each site based on actual minimum temperature (U.S. Department of Agriculture, 2012). temperatures in that region did not result in winter-kill of plant tissue. The minimum winter temperature before the start of each growing season in January at each site (Table 2) and the mean cane survival rating averaged across surviving cultivars (assessed a few months later as the growing season commenced and dead tissue was evident; Tables 3-6) were significantly and positively correlated $(r=$ $0.829, P=0.001$ ).

Most cultivars had $100 \%$ survival at all sites (Tables 3-7). Three roses ('Brite Eyes', 'Prairie Joy', and 'Yellow Submarine') had one or no surviving plants by the end of the trial at Haysville, KS; Moorhead, MN; or Rosemount, MN. At those respective sites these cultivars were not included in the site specific ANOVAs, or if a northcentral U.S. site, the cultivar was not included in the combined ANOVA for the three north-central U.S. sites.

For monthly horticultural rating, highly significant differences were found at all sites for cultivar $(P \leq$ $0.001)$, rating time $(P \leq 0.001)$, and the cultivar $\times$ rating time interaction $(P \leq 0.001)$. The block effect at each site was not significant $(P>0.05)$. Horticultural rating by month over years at the different sites is presented in a series of graphs to highlight changes in horticultural rating throughout the growing season by cultivar (Supplemental Fig. 1).

In the combined ANOVA for the three north-central U.S. sites (horticultural rating as the dependent variable), there were highly significant differences among sites $(P<0.001)$ with each site significantly different from the other. Moorhead, MN, had the highest overall rating (6.9); Ames, IA, was in the middle (5.8); and Rosemount, $\mathrm{MN}$, had the lowest overall rating (5.3) (Tables 3-5). The cultivar $\times$ northern location interaction was also highly significant $(P<0.001)$. Comparing the average horticultural rating monthly means for north-central U.S. sites, the ratings for most roses were comparable in June, but then scores tended to decline as the season progressed, except for the Moorhead, MN site which had more consistent ratings throughout the season (Supplemental Fig. 1).

Strong positive correlations for cultivar horticultural rating were generally found within sites between evaluation years (Table 8). Moorhead, 


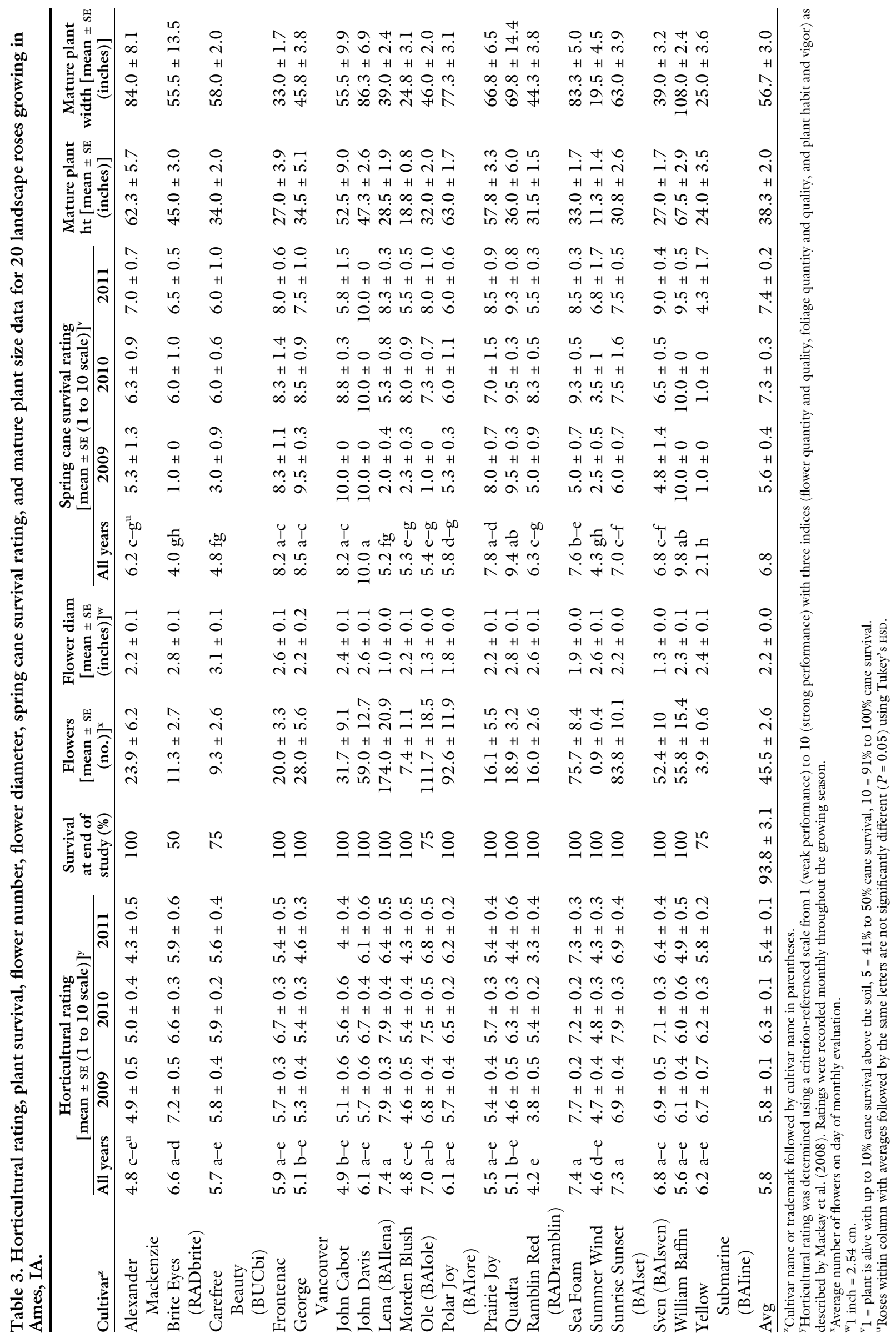




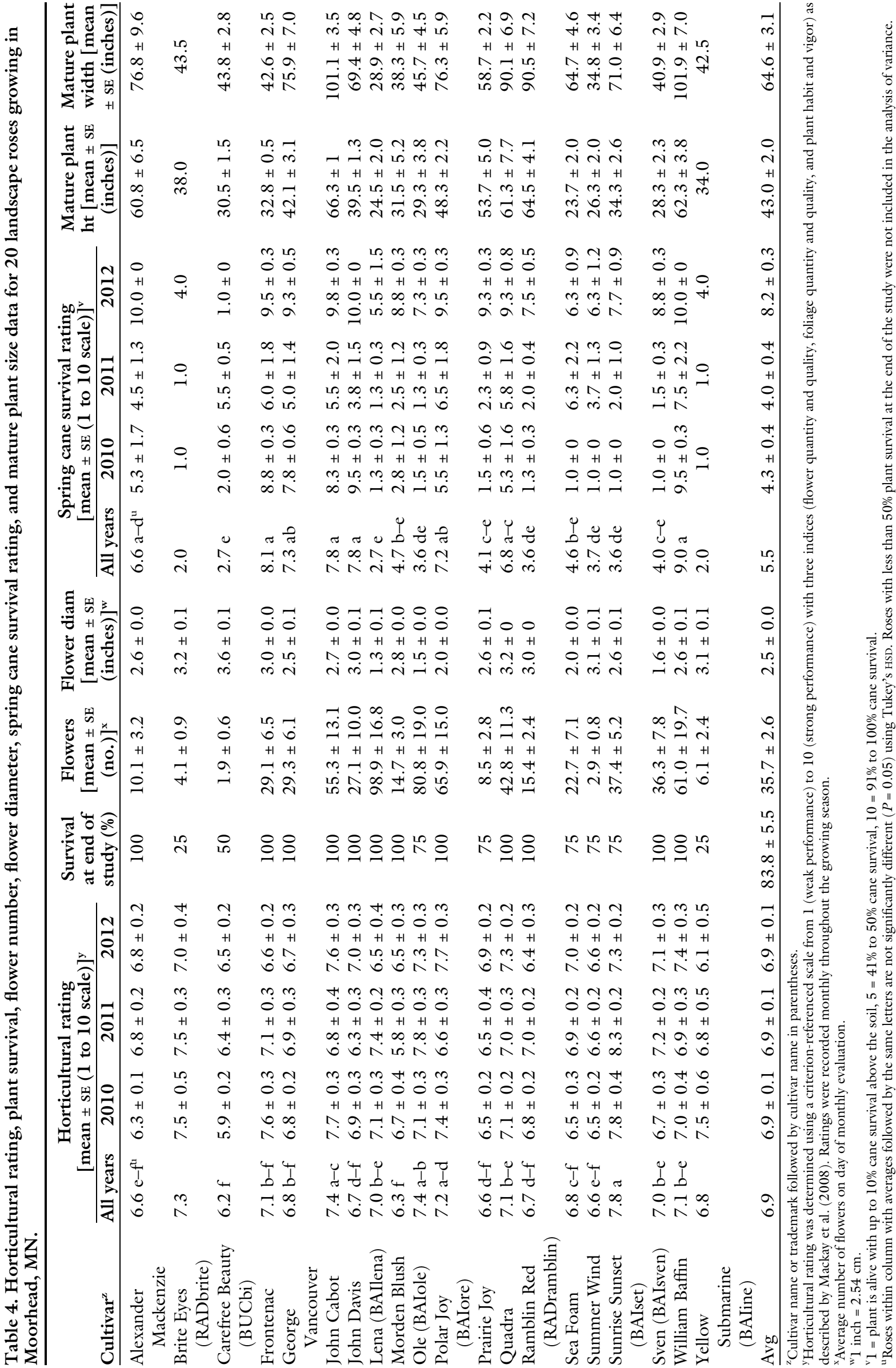




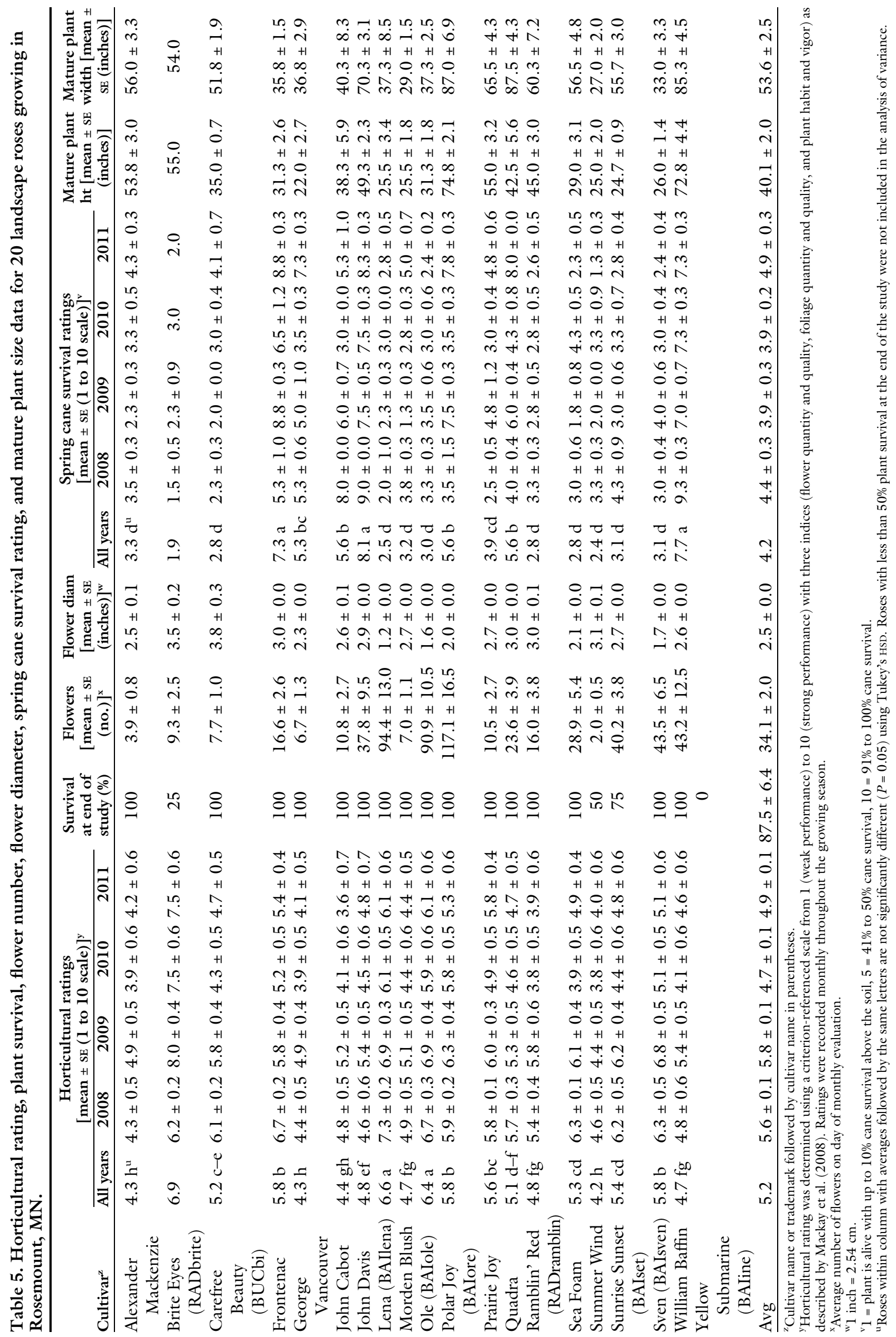




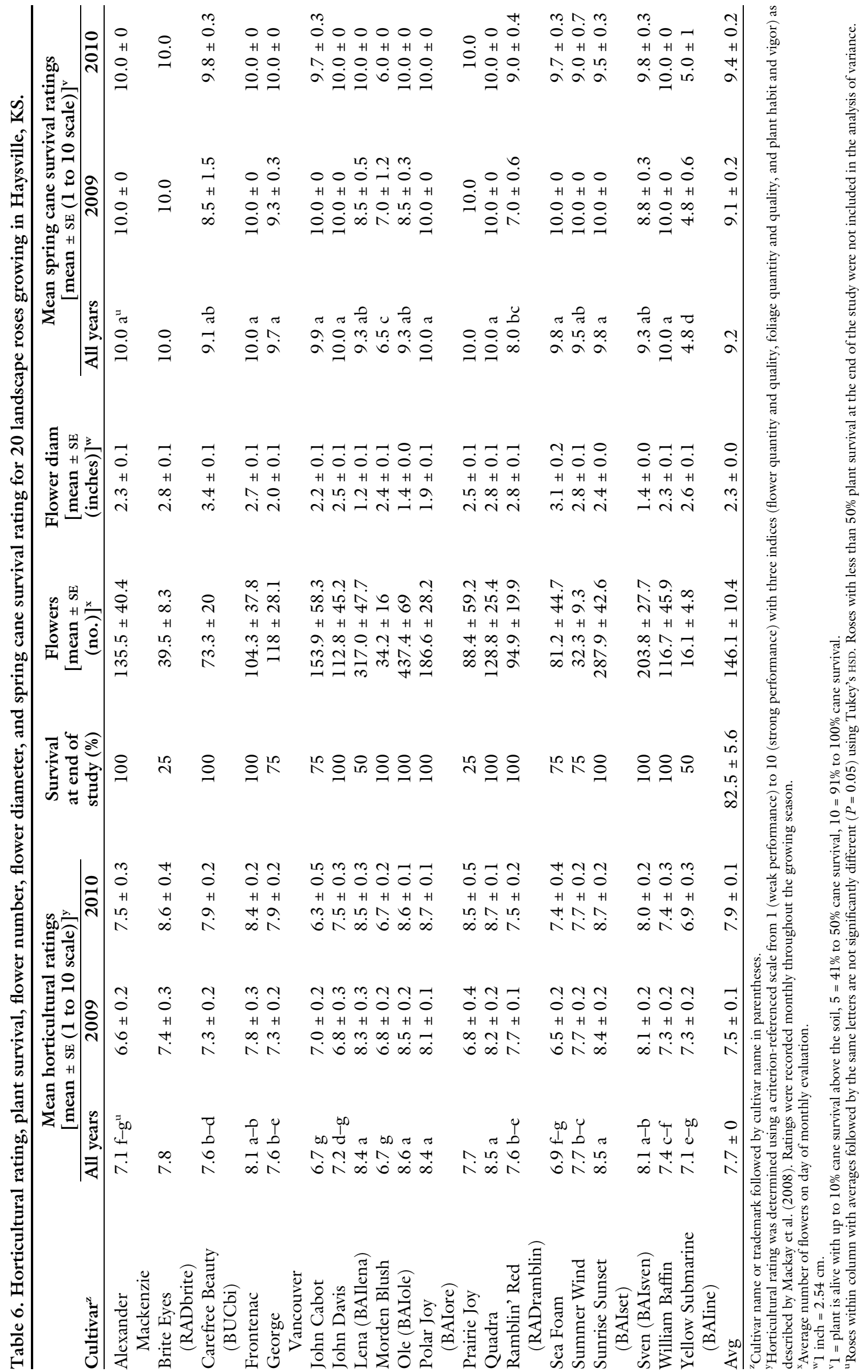


Table 7. Horticultural rating, flower number, and flower diameter for 20 landscape roses growing at Commerce, TX.

\begin{tabular}{|c|c|c|c|c|c|c|}
\hline \multirow[b]{2}{*}{ Cultivar $^{\mathrm{z}}$} & \multicolumn{3}{|c|}{$\begin{array}{c}\text { Horticultural rating } \\
{[\text { mean } \pm \text { SE }(1 \text { to } 10 \text { scale })]^{y}}\end{array}$} & \multirow{2}{*}{$\begin{array}{l}\text { Survival } \\
\text { at end of } \\
\text { study (\%) }\end{array}$} & \multirow{2}{*}{$\begin{array}{c}\text { Flowers } \\
{\left[\begin{array}{c}\text { mean } \pm S E \\
(\text { no. })]^{x}\end{array}\right.}\end{array}$} & \multirow{2}{*}{$\begin{array}{c}\text { Flower diam } \\
{[\text { mean } \pm S E} \\
(\text { inches })]^{\mathrm{w}}\end{array}$} \\
\hline & All years & $\begin{array}{l}\text { July } 2009 \text { to } \\
\text { June } 2010\end{array}$ & $\begin{array}{l}\text { July } 2010 \text { to } \\
\text { June } 2011\end{array}$ & & & \\
\hline Alexander Mackenzie & $4.1 \mathrm{~h}-\mathrm{j}^{\mathrm{v}}$ & $4.1 \pm 0.2$ & $4.1 \pm 0.2$ & 100 & $2.6 \pm 1.4$ & $1.9 \pm 0.2$ \\
\hline Brite Eyes (RADbrite) & $5.4 \mathrm{a}-\mathrm{e}$ & $5.3 \pm 0.2$ & $5.5 \pm 0.2$ & 100 & $1.3 \pm 0.4$ & $2.7 \pm 0.3$ \\
\hline Carefree Beauty (BUCbi) & $5.7 \mathrm{a}-\mathrm{c}$ & $5.9 \pm 0.1$ & $5.4 \pm 0.2$ & 100 & $3.9 \pm 1.1$ & $2.8 \pm 0.2$ \\
\hline John Cabot & $4.9 \mathrm{c}-\mathrm{g}$ & $5.2 \pm 0.2$ & $4.6 \pm 0.2$ & 100 & $9.4 \pm 4.0$ & $2.1 \pm 0.1$ \\
\hline John Davis & $5.1 \mathrm{c}-\mathrm{f}$ & $5.1 \pm 0.2$ & $5.1 \pm 0.2$ & 100 & $6.2 \pm 2.6$ & $2.2 \pm 0.2$ \\
\hline Lena (BAIlena) & $5.6 \mathrm{a}-\mathrm{c}$ & $6.2 \pm 0.2$ & $5.1 \pm 0.3$ & 100 & $25.8 \pm 5.6$ & $1.0 \pm 0.0$ \\
\hline Morden Blush & $4.5 \mathrm{~g}-\mathrm{i}$ & $4.6 \pm 0.2$ & $4.3 \pm 0.3$ & 100 & $1.4 \pm 0.3$ & $2.1 \pm 0.2$ \\
\hline Ole (BAIole) & $6.0 \mathrm{a}$ & $5.9 \pm 0.2$ & $6.1 \pm 0.3$ & 100 & $31.0 \pm 10.7$ & $1.5 \pm 0.3$ \\
\hline Polar Joy (BAIore) & $4.6 \mathrm{f}-\mathrm{h}$ & $4.6 \pm 0.1$ & $4.5 \pm 0.2$ & 100 & $21.8 \pm 5.5$ & $1.5 \pm 0.1$ \\
\hline Sea Foam & $5.7 \mathrm{a}-\mathrm{b}$ & $5.5 \pm 0.2$ & $6.0 \pm 0.2$ & 100 & $13.2 \pm 4.5$ & $1.7 \pm 0.1$ \\
\hline Summer Wind & $3.9 \mathrm{i}-\mathrm{j}$ & $4.5 \pm 0.2$ & $3.1 \pm 0.5$ & 50 & $2.7 \pm 1.4$ & $2.6 \pm 0.2$ \\
\hline Sunrise Sunset (BAIset) & $6.0 \mathrm{a}$ & $5.7 \pm 0.2$ & $6.3 \pm 0.3$ & 100 & $20.1 \pm 6.2$ & $1.9 \pm 0.1$ \\
\hline Sven (BAIsven) & $5.7 \mathrm{a}-\mathrm{b}$ & $5.5 \pm 0.3$ & $6.0 \pm 0.3$ & 75 & $18.5 \pm 5.9$ & $1.2 \pm 0.1$ \\
\hline William Baffin & $4.8 \mathrm{e}-\mathrm{g}$ & $4.9 \pm 0.2$ & $4.7 \pm 0.2$ & 100 & $6.0 \pm 3.2$ & $2.2 \pm 0.2$ \\
\hline Yellow Submarine (BAIine) & $5.8 \mathrm{a}$ & $5.7 \pm 0.1$ & $5.9 \pm 0.2$ & 100 & $5.8 \pm 2.0$ & $2.6 \pm 0.1$ \\
\hline Avg & 5.1 & $5.2 \pm 0.0$ & $5.0 \pm 0.1$ & $96.3 \pm 2.7$ & $10.1 \pm 1.0$ & $2.0 \pm 0.0$ \\
\hline
\end{tabular}

${ }^{\mathrm{z}}$ Cultivar name or trademark followed by cultivar name in parentheses.

${ }^{y}$ Horticultural rating was determined using a criterion-referenced scale from 1 (weak performance) to 10 (strong performance) with three indices (flower quantity and quality, foliage quantity and quality, and plant habit and vigor) as described by Mackay et al. (2008). Ratings were recorded monthly throughout the growing season.

${ }^{x}$ Average number of flowers on day of monthly evaluation.

${ }^{\mathrm{w}} \mathrm{l}$ inch $=2.54 \mathrm{~cm}$.

'Roses within column with averages followed by the same letters are not significantly different $(P=0.05)$ using Tukey's HSD.

$\mathrm{MN}$, is the only site where some yearly comparisons were not significantly correlated. There were also significant positive correlations for overall horticultural rating between most sites (Table 9). Between sites there were highly significant positive correlations $(r \geq 0.803, P<0.001)$ for all pairwise comparisons for flower number and flower diameter (Table 10).

Significant correlations were found between overall cultivar means for certain traits within sites (Table l1). There were significant negative correlations between flower number and flower diameter and significant positive correlations between flower number and horticultural rating at all sites. Plant height and width were significantly and positively correlated at all north-central U.S. sites along with plant height or width and cane survival ratings at some of the north-central U.S. sites. Correlations between overall mean spring cane survival ratings and overall horticultural ratings were not significant at any site. Black spot (race 3) lesion length data from detached leaf assays (Zlesak et al., 2010) were significantly and negatively correlated

Table 8. Pearson correlation values and significance within trial sites between years for mean horticultural ratings for a group of 20 landscape rose cultivars.

Years being compared

\begin{tabular}{lccc}
\hline North-central U.S. sites & & & \\
Ames, IA & $2009 / 2010$ & $2010 / 2011$ & $2009 / 2011$ \\
& $0.815^{* * *}$ & $0.855^{* * *}$ & $0.884^{* * *}$ \\
Moorhead, MN & $2010 / 2011$ & $2011 / 2012$ & $2010 / 2012$ \\
& $0.515^{* *}$ & $0.270^{\mathrm{Ns}}$ & $0.349^{\mathrm{Ns}}$ \\
Rosemount, MN & $2008 / 2009$ & $2009 / 2010$ & $2008 / 2010$ \\
& $0.784^{* * *}$ & $0.854^{* * *}$ & $0.635^{* *}$ \\
Central U.S. site & $2008 / 2011$ & $2009 / 2011$ & $2010 / 2011$ \\
Haysville, KS & $0.689^{* * *}$ & $0.869^{* * *}$ & $0.927^{* * *}$ \\
& & & \\
South-central U.S. site & $2009 / 2010$ & & \\
Commerce, TX & $0.651^{* *}$ & & \\
\hline
\end{tabular}

${ }^{\mathrm{z}}$ Due to logistical challenges from extreme drought in late 2011 at Commerce, TX, the mean horticultural rating by calendar year was not used. The two growing seasons data used for analysis were the mean horticultural ratings from July 2009 to June 2010 and July 2010 to June 2011 .

${ }_{\mathrm{Ns},}{ }^{* *},{ }^{* *}$ Nonsignificant and significant at $P \leq 0.01$ and 0.001 , respectively.

with overall horticultural rating at Ames, IA; Commerce, TX; and Rosemount, MN.

The weighted means (cultivar means weighted equally by location to account for slight differences in plant survival at the different sites) and mean separation are presented in Table 12 for the combined three north-central U.S. trial sites for horticultural rating and cane survival. There were six roses that had $\geq 75 \%$ plant survival at the end of the study and were in the top $50 \%$ of performers for 
Table 9. Pearson correlation values and significance between trial sites for overall mean horticultural ratings for a group of 20 landscape roses.

\begin{tabular}{|c|c|c|c|c|c|}
\hline & Ames, IA & Moorhead, MN & Rosemount, $\mathrm{MN}$ & Haysville, KS & Commerce, TX \\
\hline Ames, IA & & 0.479 * & $0.738 * * *$ & $0.409^{\mathrm{Ns}}$ & $0.806^{* * *}$ \\
\hline Moorhead, MN & & & $0.412^{\mathrm{Ns}}$ & $0.513^{*}$ & $0.394^{\mathrm{Ns}}$ \\
\hline Rosemount, MN & & & & $0.613 * *$ & $0.593 * *$ \\
\hline Haysville, KS & & & & & $0.341^{\mathrm{Ns}}$ \\
\hline
\end{tabular}

Ns, ${ }^{*},{ }^{* *},{ }^{* * *}$ Nonsignificant and significant at $P \leq 0.01,0.05$, and 0.001 , respectively.

Table 10. Pearson correlation values and significance between trial sites for overall mean flower number (upper right) and overall mean flower diameter (lower left) for a collection of 20 landscape rose cultivars.

\begin{tabular}{|c|c|c|c|c|c|}
\hline & Ames, IA & Moorhead, MN & Rosemount, MN & Haysville, KS & Commerce, TX \\
\hline Ames, IA & 一 & $0.852 * * *$ & $0.865^{* * *}$ & $0.813^{* * *}$ & $0.870 * * *$ \\
\hline Moorhead, MN & $0.983^{* * *}$ & - & $0.830 * * *$ & $0.802 * * *$ & $0.782 * * *$ \\
\hline Rosemount, MN & $0.973 * * *$ & $0.977 * * *$ & - & $0.739 * * *$ & $0.863^{* * *}$ \\
\hline Haysville, KS & $0.885^{* * *}$ & $0.855^{* * *}$ & $0.875^{* * *}$ & - & $0.899 * * *$ \\
\hline Commerce, TX & $0.927 * * *$ & $0.935 * * *$ & $0.959 * * *$ & $0.836 * * *$ & - \\
\hline
\end{tabular}

*** Significant at $P<0.001$.

Table 11. Pearson correlation values and significance between overall mean values of selected traits for a group of 20 landscape roses grown at five locations.

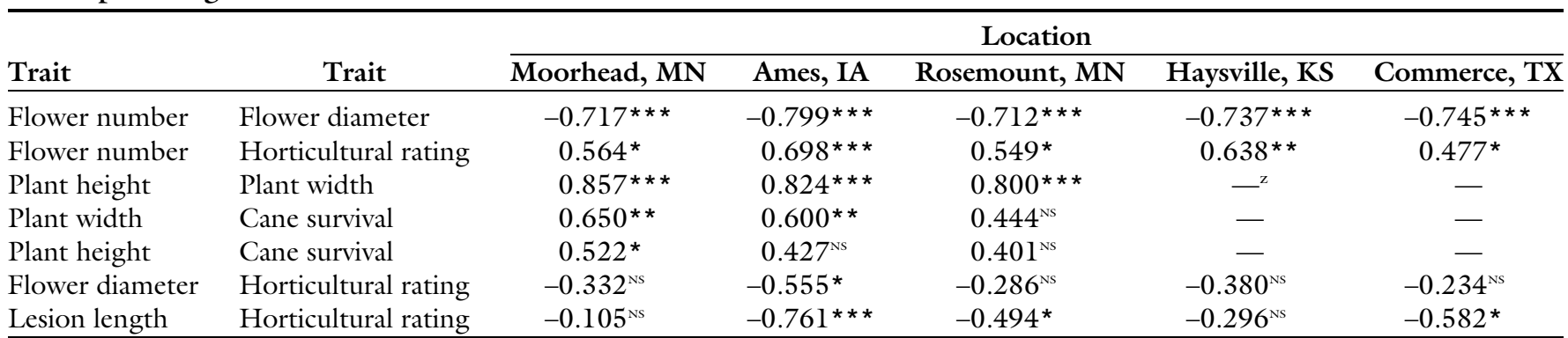

${ }^{\mathrm{z}}$ Correlation could not be performed due to data for at least one trait not collected at the location.

Ns, ${ }^{*},{ }^{* *},{ }^{* *}$ Nonsignificant and significant at $P=0.05,0.01$, and 0.001 , respectively.

overall mean horticultural rating at all three sites (Tables 3-5). They were: 'Lena', 'Frontenac', 'Ole', 'Polar Joy', 'Sunrise Sunset', and 'Sven'. Of the six roses, 'Frontenac', 'Ole', 'Polar Joy', 'Sunrise Sunset', and 'Sven' also met the same criteria at Haysville, $\mathrm{KS}$, and 'Lena', 'Frontenac', 'Ole', 'Sunrise Sunset', and 'Sven' met the same criteria at Commerce, TX. This suggests that there are rose cultivars that can experience moderate to severe dieback and then recover vigorously to flower and perform well.

\section{Discussion}

Low-input, multiyear, multilocation trials that represent different regional growing conditions provide valuable information on which to base cultivar recommendations important to a wide range of stakeholder groups (e.g., breeders, production nurseries, landscapers, retail garden centers, and homeowners). This is especially true for woody species, such as roses, that mature over multiple seasons. Over seasons, not only do climatic factors such as temperature and moisture vary, but disease and pest pressures can also change over time. Such variations in abiotic and biotic stressors can magnify performance differences among cultivars as plants age and support the benefit of multiyear trials.

Death of rose plants from winterkill and unsightly defoliation from diseases and pests have been major challenges in the north-central United States with many of the nationally distributed landscape rose cultivars. Fortunately, there is a wide range of cold hardiness, plant health, and overall performance available among landscape rose cultivars as documented in this and other landscape rose field studies (Carlson-Nilsson and Davidson, 2009). The more broadly the results from regional plant performance trials are communicated to stakeholders, the more stakeholders can benefit by being pointed to those cultivars with documented strong regional performance.

'Brite Eyes' and 'Yellow Submarine' had the most winterkill at the north-central U.S. sites (they had $<50 \%$ plant survival by the end of the study at the two coldest sites). These roses were relatively new to the market when the study began and were included because preliminary reports were positive. These roses are marketed as hardy to Zone 5 and our data supports that they should not be recommended in Zones 3 and 4 without winter protection (insulation).

Most of the roses in the trial were developed within or near the northcentral region of the United States. Strong spring vigor compensating for winter cane loss has been a trait that 
Table 12. Overall horticultural and spring cane survival ratings for a group of 18 landscape roses grown across three north-central U.S. trial sites (Ames, IA; Moorhead, MN; and Rosemount, $\mathrm{MN}$ ).

\begin{tabular}{lcc}
\hline Cultivar $^{\mathbf{z}}$ & Horticultural rating $^{\mathbf{y}}$ & Cane survival $^{\mathbf{x}}$ \\
\hline Alexander Mackenzie & $5.2 \mathrm{hi}^{\mathrm{w}}$ & $4.7 \mathrm{de}$ \\
Carefree Beauty (BUCbi) & $5.7 \mathrm{fg}$ & $2.9 \mathrm{~g}$ \\
Frontenac & $6.3 \mathrm{~cd}$ & $7.5 \mathrm{ab}$ \\
George Vancouver & $5.3 \mathrm{~g}-\mathrm{i}$ & $6.2 \mathrm{c}$ \\
John Cabot & $5.6 \mathrm{fg}$ & $6.8 \mathrm{bc}$ \\
John Davis & $5.7 \mathrm{fg}$ & $8.3 \mathrm{a}$ \\
Lena (BAIlena) & $6.9 \mathrm{a}$ & $3.0 \mathrm{fg}$ \\
Morden Blush & $5.3 \mathrm{~g}-\mathrm{i}$ & $3.7 \mathrm{e}-\mathrm{g}$ \\
Ole (BAIole) & $6.8 \mathrm{ab}$ & $3.7 \mathrm{e}-\mathrm{g}$ \\
Polar Joy (BAIore) & $6.4 \mathrm{~b}-\mathrm{d}$ & $5.8 \mathrm{~cd}$ \\
Prairie Joy & $5.8 \mathrm{ef}$ & $4.7 \mathrm{de}$ \\
Quadra & $5.8 \mathrm{ef}$ & $6.2 \mathrm{bc}$ \\
Ramblin' Red (RADramblin) & $5.5 \mathrm{f}-\mathrm{h}$ & $3.7 \mathrm{e}-\mathrm{g}$ \\
Sea Foam & $6.2 \mathrm{de}$ & $4.3 \mathrm{ef}$ \\
Summer Wind & $5.0 \mathrm{i}$ & $3.4 \mathrm{fg}$ \\
Sunrise Sunset (BAIset) & $6.6 \mathrm{a}-\mathrm{c}$ & $4.3 \mathrm{ef}$ \\
Sven (BAIsven) & $6.5 \mathrm{~b}-\mathrm{d}$ & $4.1 \mathrm{e}-\mathrm{g}$ \\
William Baffin & $5.7 \mathrm{fg}$ & $8.6 \mathrm{a}$ \\
Avg & 5.9 & 5.7 \\
\hline
\end{tabular}

${ }^{\mathrm{z}}$ Cultivar name or trademark followed by cultivar name in parentheses.

${ }^{y}$ Horticultural rating was determined using a criterion-referenced scale from 1 (weak performance) to 10 (strong performance) with three indices (flower quantity and quality, foliage quantity and quality, and plant habit and vigor) as described by Mackay et al. (2008). Ratings were recorded monthly throughout the growing season.

${ }^{\mathrm{x}} \mathrm{l}=$ plant is alive with up to $10 \%$ cane survival above the soil, $5=41 \%$ to $50 \%$ cane survival, $10=91 \%$ to $100 \%$ cane survival.

${ }^{\text {w }}$ Roses within columns with averages followed by the same letters are not significantly different $(P=0.05)$ using Tukey's HSD. The means presented are weighted by location to account for differences in numbers of plants across locations due to mortality. The roses presented have $\geq 50 \%$ at the end of the study at all locations.

some cold climate breeders have purposely prioritized (K. Zuzek, personal communication). Selection for fast regrowth after severe winter dieback may contribute to the lack of significant correlation between spring cane survival and horticultural ratings. Nevertheless, roses need enough winterhardiness to routinely and adequately survive winter and still have enough tissue left to recover.

Fungal diseases can damage foliage and other plant organs and compromise overall plant performance. In locations where conditions are conducive to the development of black spot, this disease is often the most problematic fungal disease of roses because it can proliferate quickly and lead to repeated defoliation events (Dobbs, 1984). Besides black spot, the leaf spot diseases anthracnose (Sphaceloma rosarium) and cercospora (Cercospora rosicola) are major defoliating diseases in roses (Horst and Cloyd, 2007). Leaf spot symptoms were noticeably present at some time at all the trial sites. In this study, reasons for defoliation and decreased foliage quality were not recorded because when there is missing foliage due to multiple factors, it is difficult to accurately attribute the relative contribution of each factor.

In a complementary study, all 20 roses were individually challenged with three isolates of black spot representing three different races (Zlesak et al., 2010). To rank genotypes for relative field or horizontal resistance, it is important to make comparisons between susceptible genotypes using a common isolate of a race at a common inoculation time because aggressiveness among isolates can vary and aggressiveness can also vary over time. Fortunately, black spot susceptible roses have a similar rank for lesion diameter across different isolates and races (Zlesak et al., 2010). Most of the 20 roses $(n=18)$ were susceptible to isolate GVH (Race 3) with 17 of them providing useful lesion diameter data. Therefore, lesion diameter data for isolate GVH was used for correlations. There were significant negative correlations between lesion diameter and overall horticultural rating at three of the five sites [Ames, IA; Commerce, TX; and Rosemount, MN (Table 11)]. As black spot susceptibility increased (larger lesion diameter), overall horticultural rating decreased. Two north-central U.S. sites (Ames, IA and Rosemount, $\mathrm{MN}$ ) had significant negative correlations between laboratory black spot lesion size and field horticultural rating. These sites routinely have more precipitation than the third northcentral U.S. site [Moorhead, MN (Your Weather Service, 2017)]. The Ames, IA and Rosemount, MN sites also tended to have monthly horticultural ratings that dropped sharply as the season progressed due to primarily increased defoliation from foliar diseases, unlike the Moorhead, $\mathrm{MN}$ site where horticultural ratings remained higher and more consistent throughout the growing season (Supplemental Fig. 1). The correlation between black spot lesion length and horticultural rating was also significant at Commerce, TX, but not at Haysville, KS. For these longer growing season locations, Commerce, TX, routinely has more precipitation and less wind than Haysville, KS, which may have contributed to greater disease pressure at Commerce, TX (Your Weather Service, 2017).

Highly significant negative correlations were found between flower number and flower diameter at all trial sites (Table 11). Competition for resource allocation is the likely explanation with cultivars producing larger flowers not producing as many. In addition, significant positive correlations were found at all sites for flower number and horticultural rating. Because horticultural rating is partly calculated by flower quantity and quality, more flowers should increase the horticultural rating. Although overall average flower number per plant per evaluation had a wide range across sites [10.1 to 146.1 (Tables 3-7)], there were highly significant $(P<0.001)$ positive correlations for flower number between all sites (Table 10). The extremes were Haysville, KS, with the greatest average number of flowers per evaluation [146.1 (Table 6)] and Commerce, TX, with the fewest [10.1 (Table 7)]. The three north-central sites ranged from 34.1 to 45.5 flowers per plant per evaluation (Tables 3-5). Factors such as defoliation from disease pressure, the warmest summer temperatures, and the very long growing season with slowed growth during the warm summer months in 
Commerce, TX, may have suppressed overall number of flowers per evaluation. Haysville, KS, may have had the overall greatest number of flowers per evaluation because of strong cane survival going into the growing season (compared with the north-central sites), generally sustained flowering levels throughout the season (Supplemental Fig. 1), and more moderate summer temperatures than Commerce, TX.

Significant and positive correlations at some sites between plant size and cane survival ratings may reflect, in part, that greater cane survival can lead to retained stem tissue in subsequent years helping to allow a larger mature plant size. In addition, there were stronger correlations (although not all significant) at all three north-central U.S. sites between plant width and cane survival than plant height and cane survival. This may be because wider plants are more likely to have lower, diagonally growing canes that are periodically covered with drifted snow during the winter, thereby insulating the canes. Depth and movement of snow around individual plants is quite variable during winter months and was not documented.

The extreme heat and drought during the bulk of the Summer 2011 in Commerce, TX, were abnormal. Temperatures exceeded $100{ }^{\circ} \mathrm{F}$ $\left(37.8^{\circ} \mathrm{C}\right)$ for $65 \mathrm{~d}$, and pan evaporation rates exceeded $70 \mathrm{~mm} /$ week. Although these conditions posed challenges to plant performance during the growing season and led to premature termination of data collection for this trial in Aug. 2011, they provided a new opportunity. At the close of the 2011 season, roses demonstrating different degrees of drought stress were dug and their root systems analyzed (Harp et al., 2015). Strong positive correlations were found between horticultural rating and root dry weight. In addition, root fibrosity and drought stress tolerance were positively correlated with root mass.

Multiyear and multilocation trials are critical to the identification of regionally adapted cultivars, especially when plants are grown under low-input conditions and exposed to the typical range of climatic conditions and pests (Carlson-Nilsson and Davidson, 2009; Harp et al., 2009; Zlesak et al., 2015). During multiyear, in-ground landscape rose trials there is time for larger growing cultivars to reach their mature size, fungal diseases to establish in the plots, and the cumulative effects of winter injury and disease to be observed on the performance of cultivars. Ongoing regional, multiyear landscape rose trials should continue to be established to support the horticulture community as new cultivars are introduced to continue to build and communicate regional data sets.

Finding six roses that were consistently strong performers across the three north-central U.S. trial sites [top $50 \%$ of performers for horticultural rating at each site and $\geq 75 \%$ plant survival ('Lena', 'Frontenac', 'Ole', 'Polar Joy', 'Sunrise Sunset', and 'Sven')] provides solid evidence to merit their recommendation in low maintenance landscapes in the northcentral region. Many of these roses also performed well at the central U.S. and south-central U.S. sites and data from those sites justifies continued trialing of the best performing roses at additional sites in these regions. Data across all five sites also provide interested stakeholders (breeders, marketers, nurseries, and landscapers, etc.) with preliminary information on cultivars that have a relatively broad range of climatic adaptation.

\section{Literature cited}

American Rose Society. 2007. Modern roses XXII. Pediment Publ., Battleground, WA.

Carlson-Nilsson, B.U. and C.G. Davidson. 2009. A three year study of winter hardiness and blackspot resistance (Diplocarpon rosae Wolf) of roses in two climatically different environments. Floricult. Ornamental Biotechnol. 3(special issue 1):139-151.

Dobbs, R.B. 1984. Research battles blackspot in roses. Amer. Rose Annu. 69:44-54.

Grygorczyk, A., S. Mhlanga, and I. Leescaeve. 2013. Hardy rose breeding: Consumer preferences for roses. 11 Dec. 2016. <http://vinelandresearch.com/ sites/default/files/hardy_rose_breeding consumer_preferences_for_roses.pdf $>$.

Harp, D.A., K. Kay, D.C. Zlesak, and S. George. 2015. The effect of rose root size on drought stress tolerance and landscape plant performance. Tex. J. Agr. Nat. Resour. 28:82-88.

Harp, D.A., D.C. Zlesak, G. Hammond, S George, and W. Mackay. 2009. EarthKind $^{\text {TM }}$ rose trials-Identifying the world's strongest, most beautiful landscape roses. Floricult. Ornamental Biotechnol. 3(special issue 1):166-175.

Horst, R.K. and R. Cloyd. 2007. Compendium of rose diseases and pests. 2nd ed. APS Press, St. Paul, MN.

Mackay, W.A., S.W. George, C. McKenney, J.J. Sloan, R.I. Cabrera, J.A. Reinert, P. Colbaugh, L. Lockett, and W. Crow. 2008. Performance of garden roses in north central Texas under minimal input conditions. HortTechnology 18:417-422.

Pemberton, H.B. and J.F. Karlik. 2015. A recent history of changing trends in garden rose plant sales, types, and production methods. Acta Hort. 1064:223-234.

Richer, C., J.A. Rioux, M.P. Lamy, and R. Drapeau. 2005. Impact of propagation method on the growth of 10 rose shrubs of the Explorer ${ }^{\mathrm{TM}}$ series under natural and extreme winter conditions. Can. J. Plant Sci. 86:799-807.

Svejda, F. 2008. The Canadian explorer roses. National Roses Canada, London, ON, Canada.

Svejda, F. 2014. Cv. releases: Canadian explorer roses. 14 Mar. 2017. <http:// montrealweb.ville.montreal.qc.ca/ jardin/archives/svejda/sserie_pdf_en. php?pub_id=227>.

U.S. Department of Agriculture. 2012. USDA plant hardiness zone map. 11 May 2017. <http://planthardiness.ars.usda. gov/PHZMWeb>.

Waliczek, T.M., D.J. Holeman, and D.H. Byrne. 2015. Growers' and consumers' knowledge, attitudes and opinions regarding roses available for purchase. Acta Hort. 1064:235-239.

Your Weather Service. 2017. US climate data. 11 May 2017. <http://www. usclimatedata.com>.

Zlesak, D.C., D.A. Harp, K. Zuzek, J.J. Sloan, A. Owings, and S.W. George. 2015. Earth-Kind ${ }^{\circledR}$ rose trialing: An international model for the identification of regionally adapted landscape roses. Acta Hort. 1064:123-129.

Zlesak, D.C., V.M. Whitaker, S. George, and S.C. Hokanson. 2010. Evaluation of roses from the Earth-Kind ${ }^{\circledR}$ Trials: Black spot (Diplocarpon rosae Wolf) resistance and ploidy. HortScience 45:1779-1787.

Zuzek, K., D. Zlesak, V.M. Whitaker, S. McNamara, and S.C. Hokanson. 2016. Northern Accents ${ }^{\circledR}$ 'Lena', 'Ole', 'Sigrid', and 'Sven': Four cold-hardy polyantha rose cultivars from the University of Minnesota woody landscape plant breeding program. HortScience 51:296-299. 

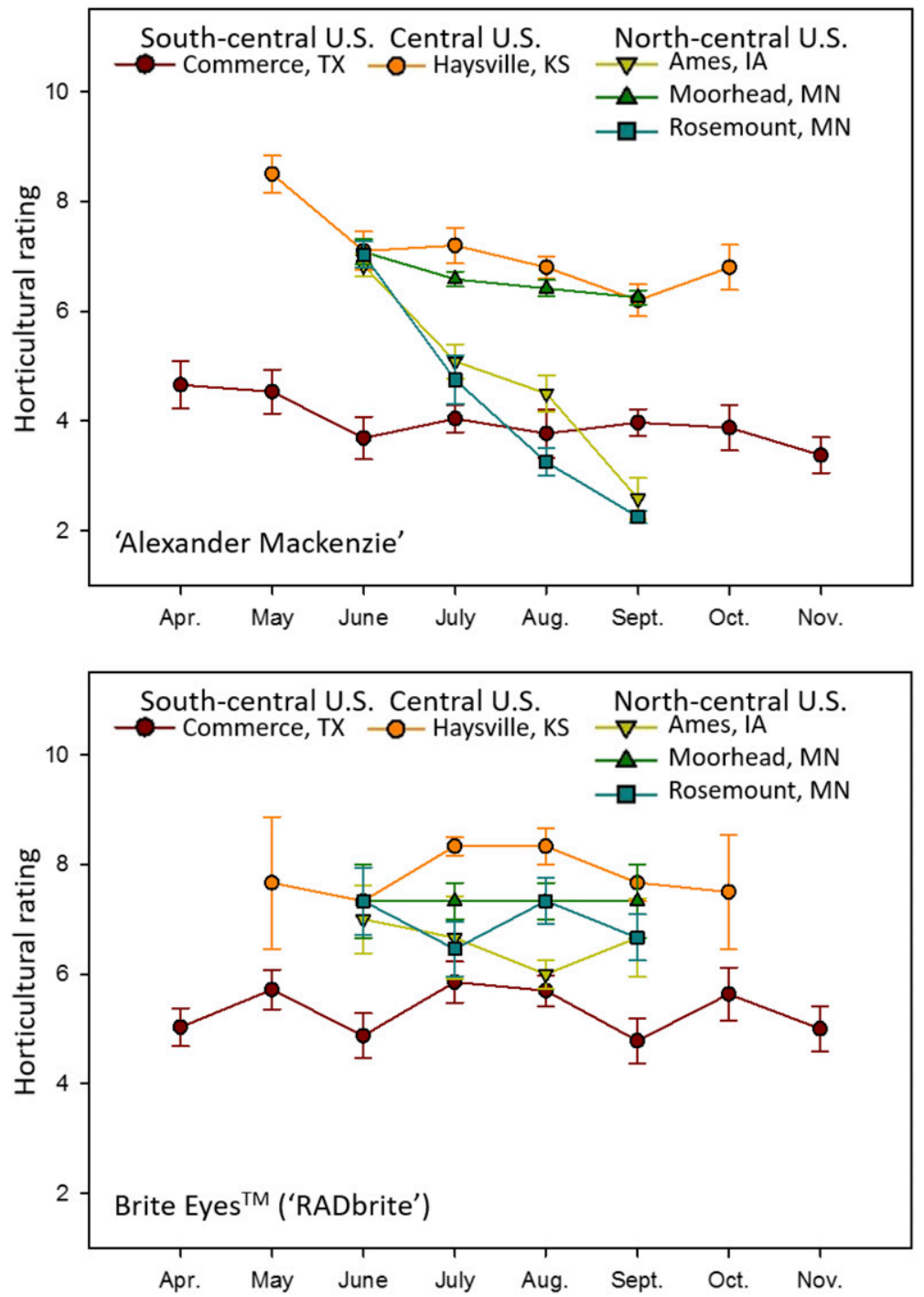

Supplemental Fig. 1. Mean monthly horticultural ratings $( \pm$ SE) over multiple years for 20 landscape roses over the growing season at five different trial locations. Horticultural rating was determined using a criterion-referenced scale from 1 (weak performance) to 10 (strong performance) with three indices (flower quantity and quality, foliage quantity and quality, and plant habit and vigor) as described by Mackay et al. (2008). 


\section{VARIETY TRIALS}
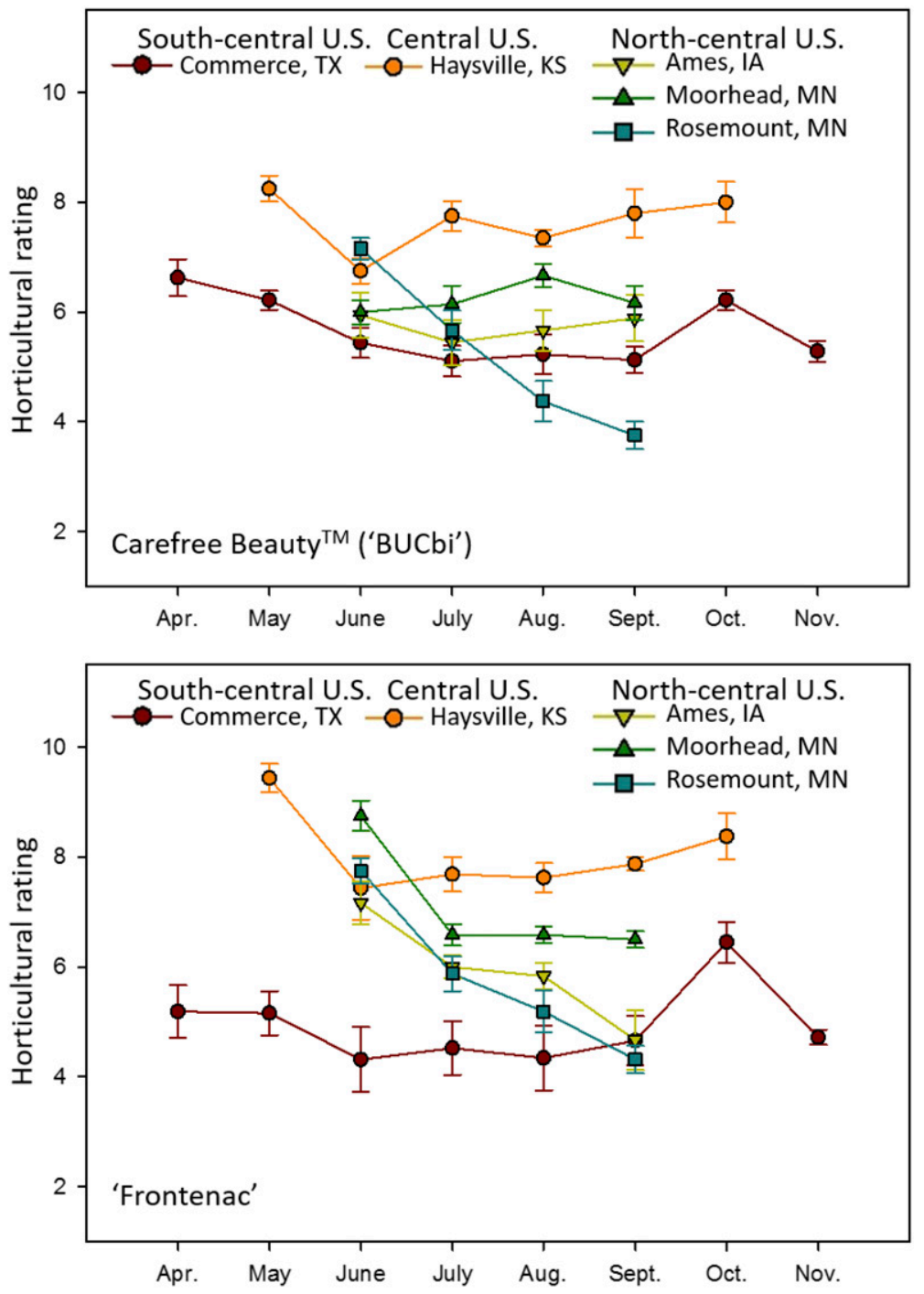

Supplemental Fig. 1. (Continued) 

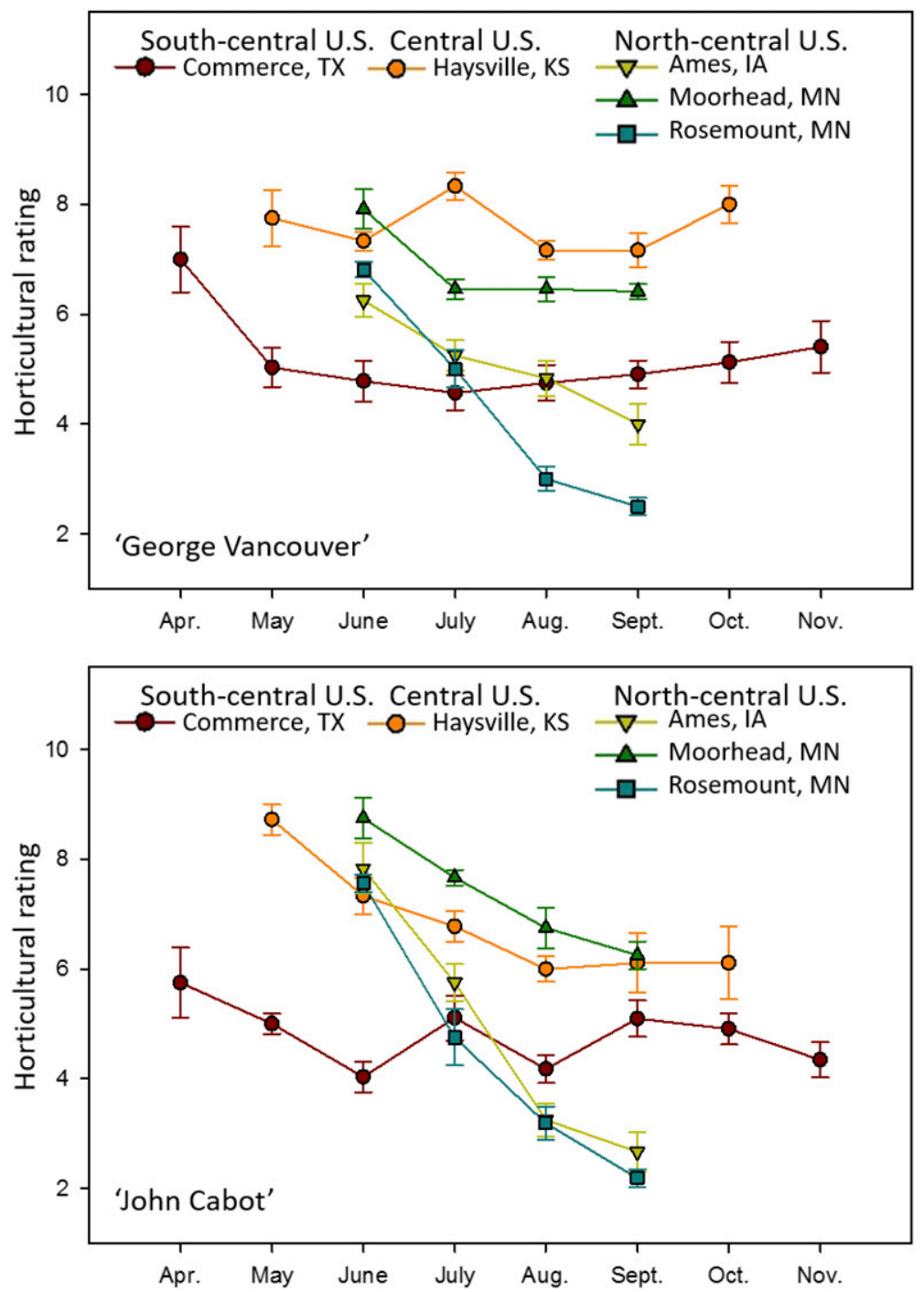

Supplemental Fig. 1. (Continued) 


\section{VARIETY TRIALS}
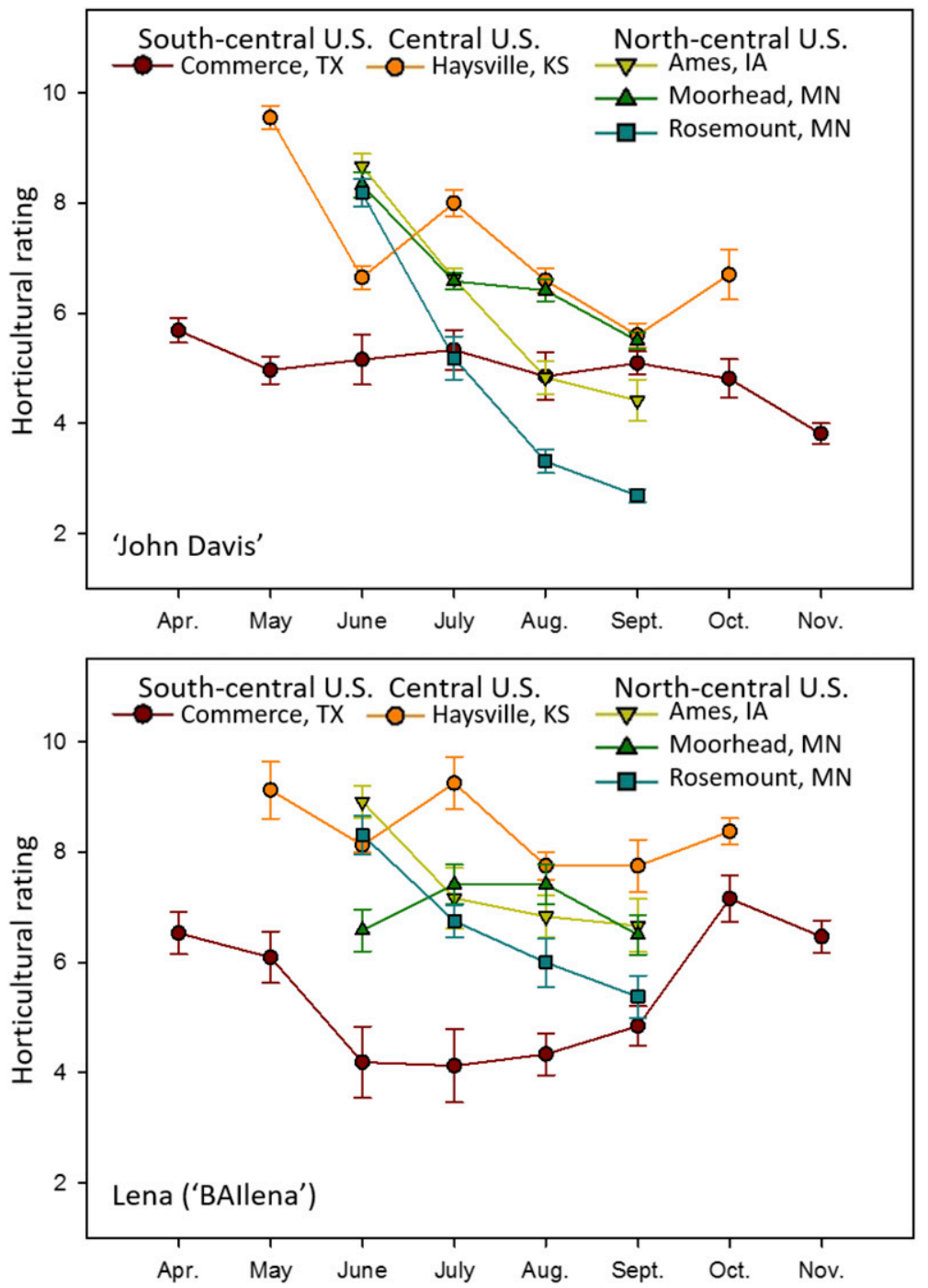

Supplemental Fig. 1. (Continued) 

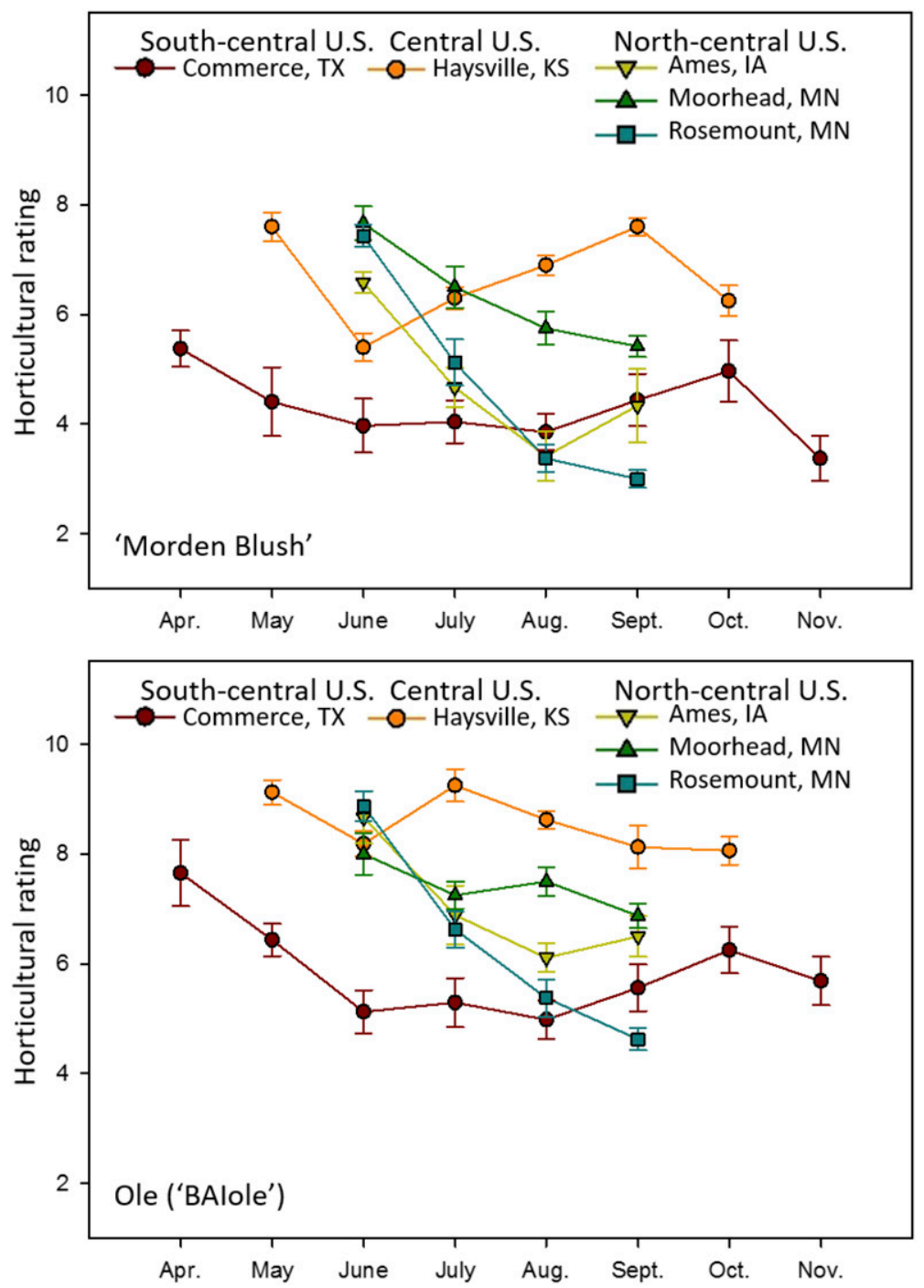

Supplemental Fig. 1. (Continued) 


\section{VARIETY TRIALS}
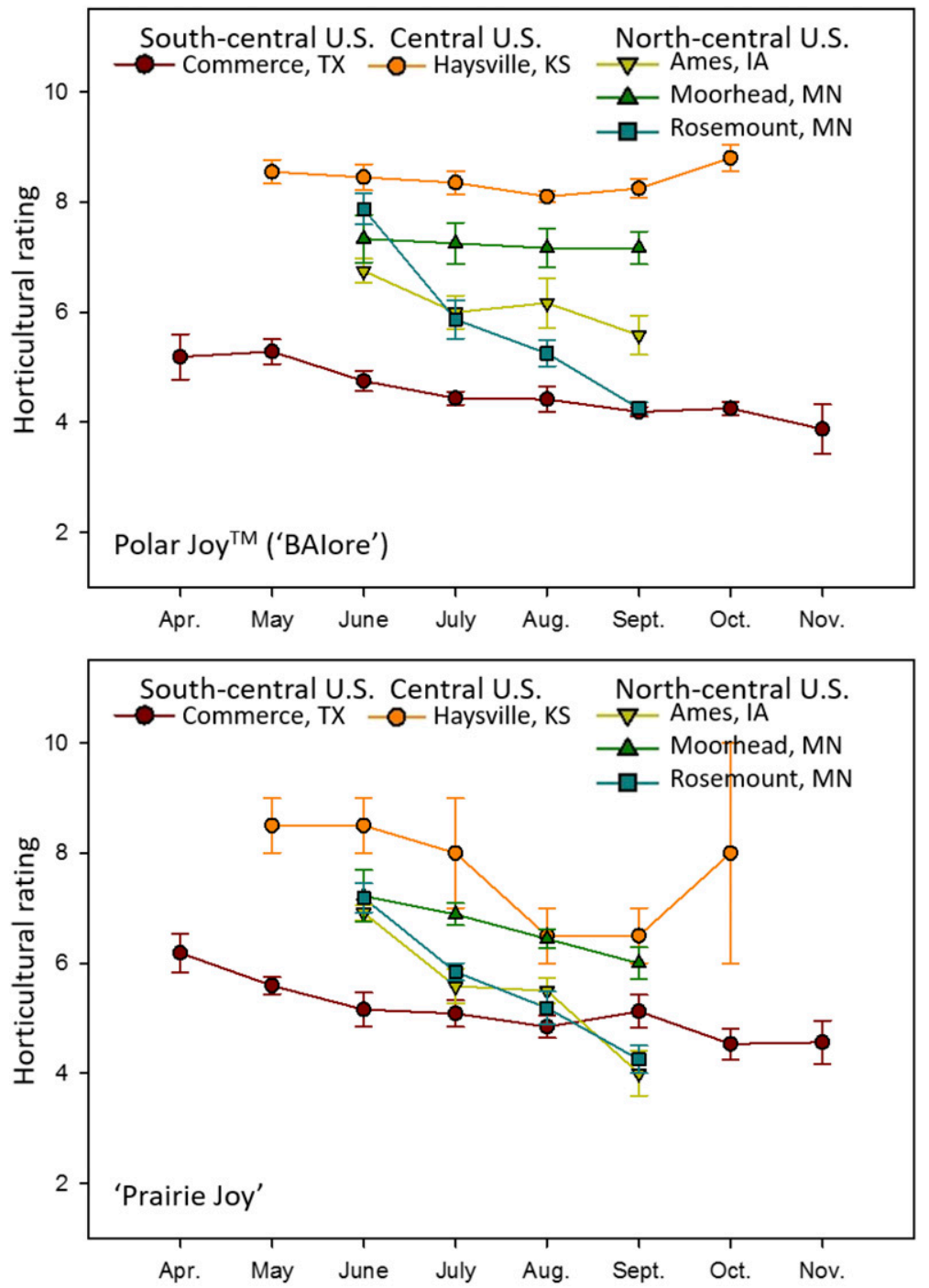

Supplemental Fig. 1. (Continued) 

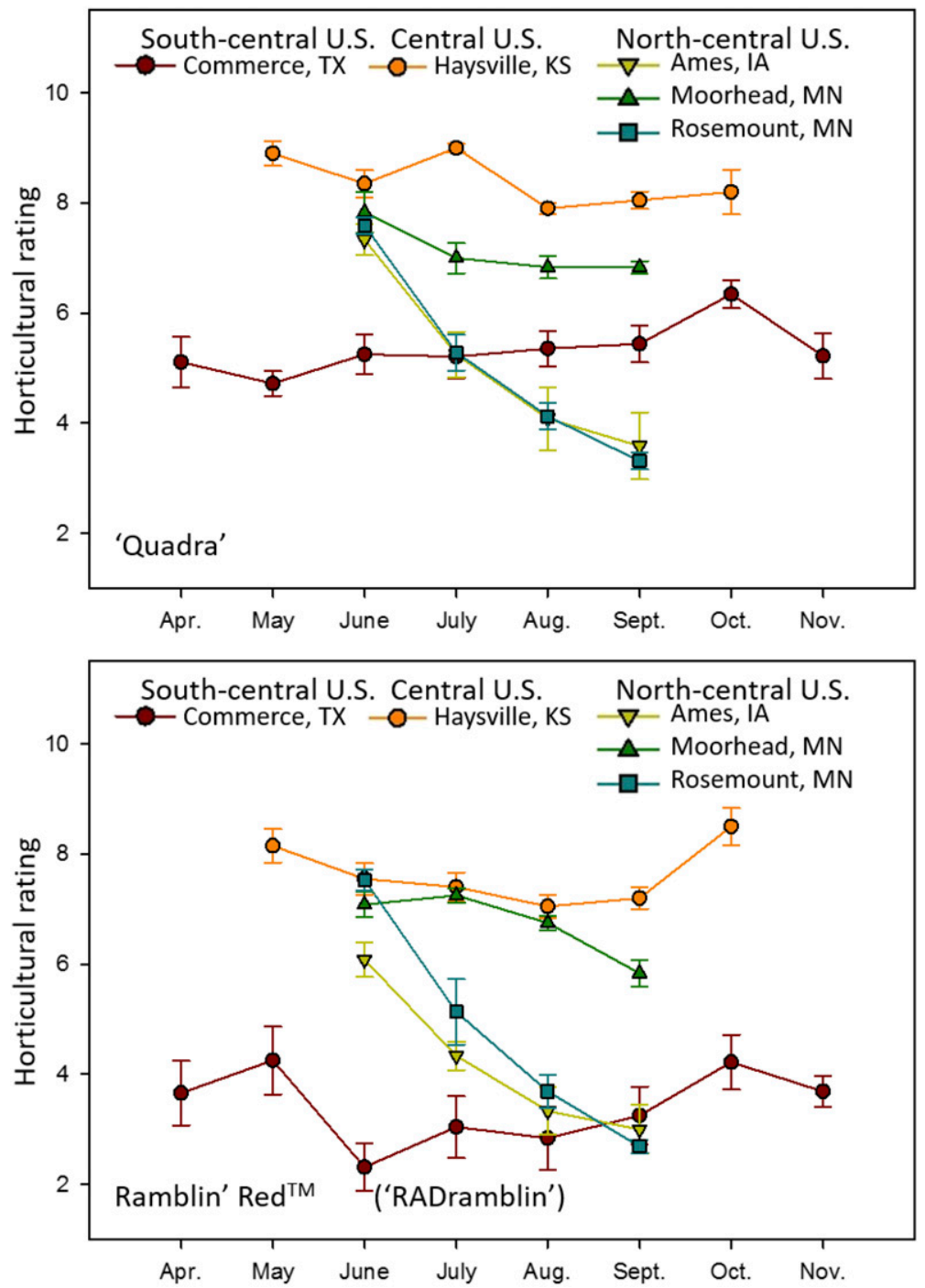

Supplemental Fig. 1. (Continued) 


\section{VARIETY TRIALS}
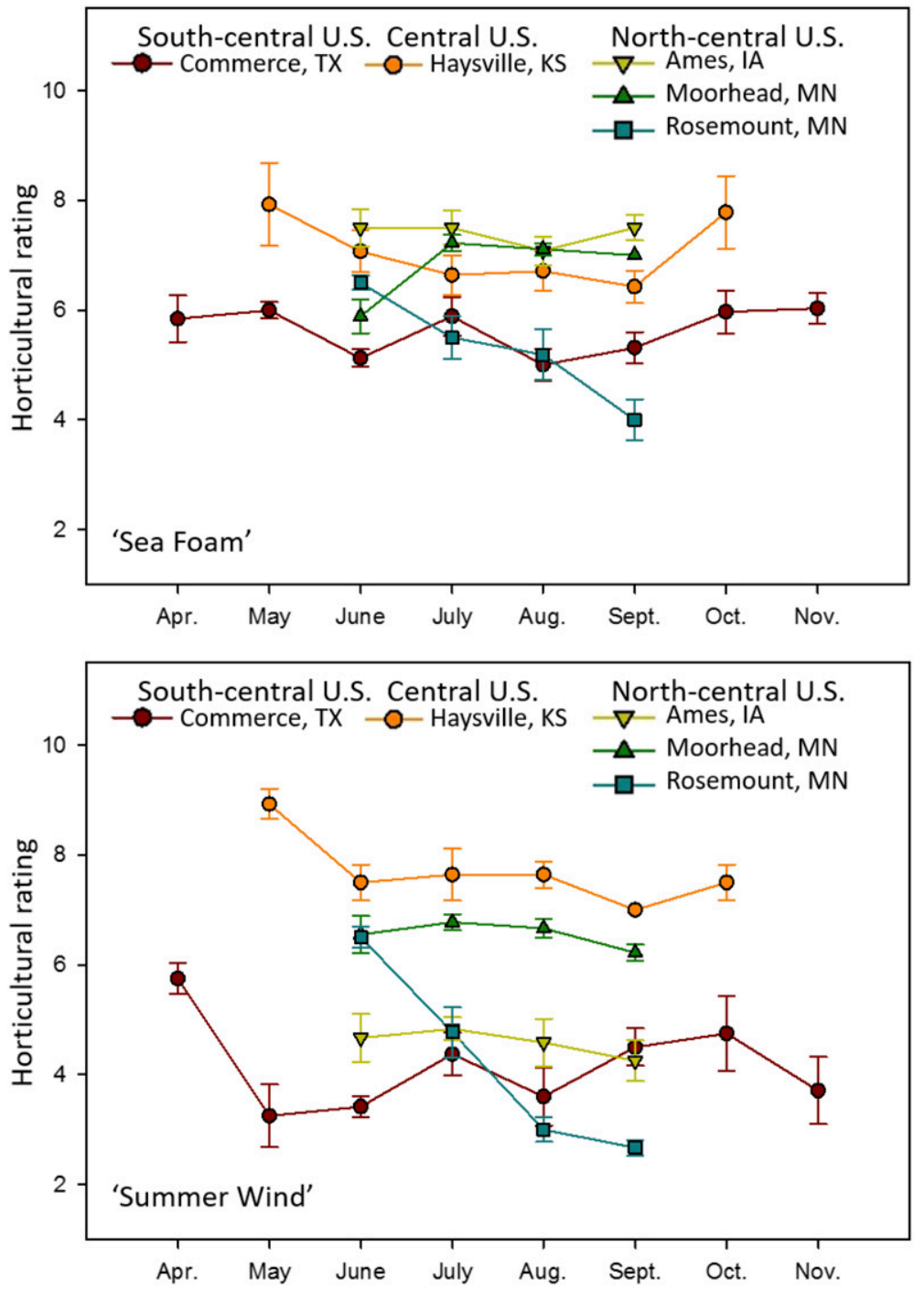

Supplemental Fig. 1. (Continued) 

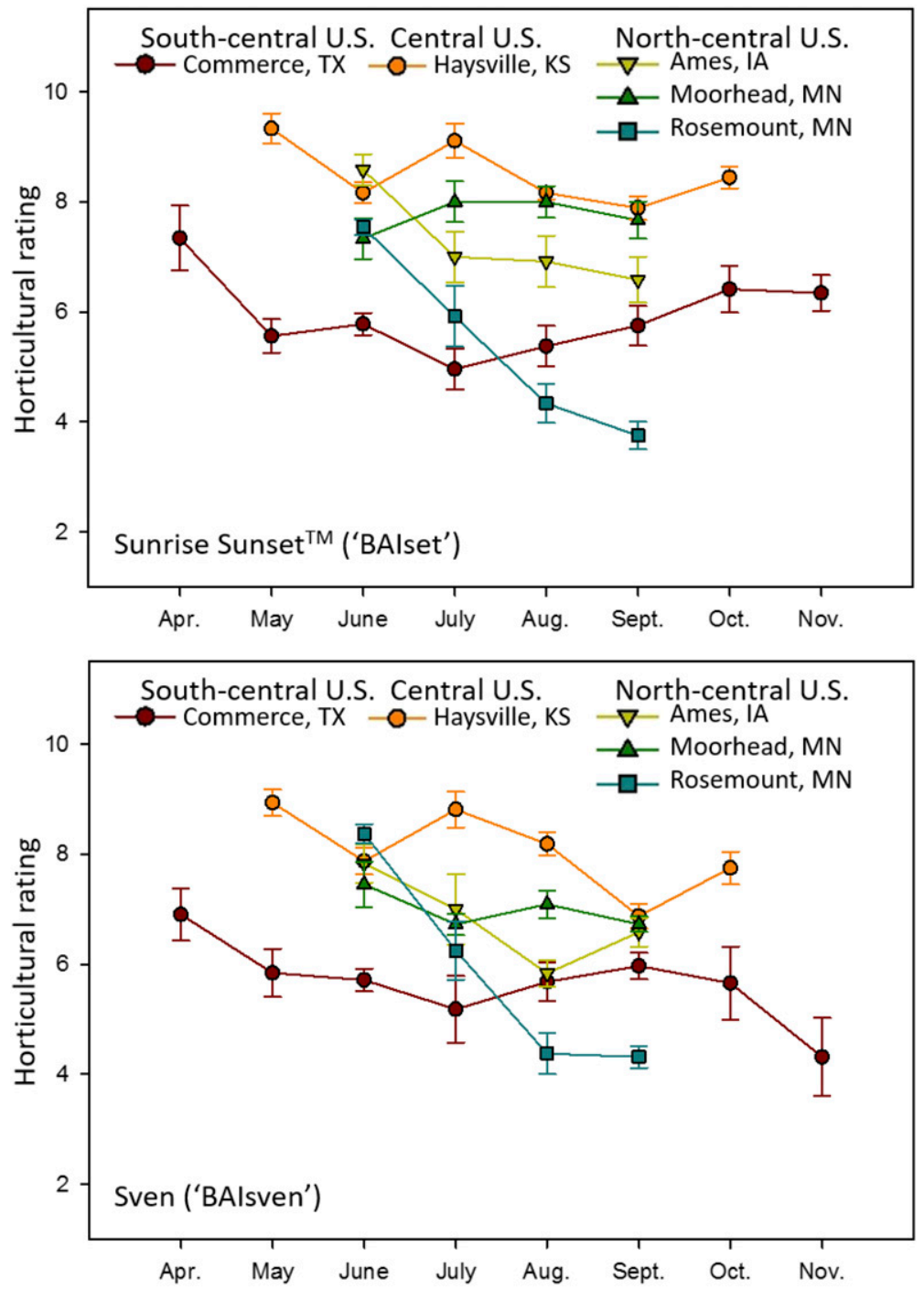

Supplemental Fig. 1. (Continued) 


\section{VARIETY TRIALS}
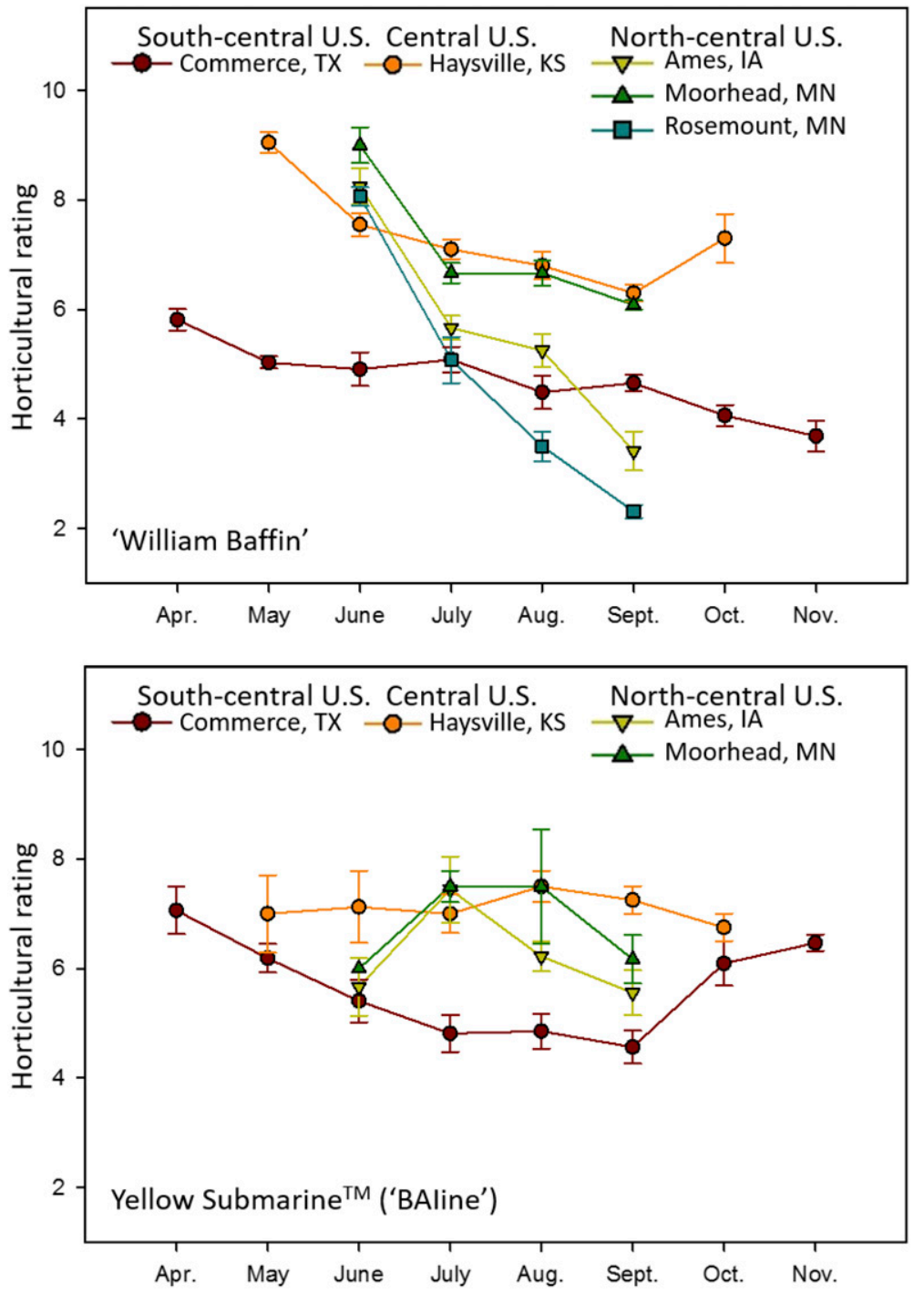

Supplemental Fig. 1. (Continued) 